\title{
Selenastraceae (Sphaeropleales, Chlorophyceae): $r b c L$, 18S rDNA and ITS-2 secondary structure enlightens traditional taxonomy, with description of two new genera, Messastrum gen. nov. and Curvastrum gen. nov.
}

\author{
Thaís Garcia da Silva ${ }^{1 *}$, Christina Bock ${ }^{2}$, Célia Leite Sant'Anna ${ }^{3}$, Inessa Lacati- \\ va BAGATINI ${ }^{1}$, Sabina WodnioK ${ }^{2} \&$ Armando Augusto Henriques VIEIRA ${ }^{1}$
}

\author{
${ }^{1}$ Laboratory of Phycology, Department of Botany, Federal University of São Carlos, Graduate Program in \\ Ecology and Natural Resources, CEP 13560-590, São Carlos, SP, Brazil; * Corresponding author e-mail: \\ thais.garcia.bio@gmail.com \\ ${ }^{2}$ Department of Biodiversity, University of Duisburg-Essen, Essen, D-45141, Germany \\ ${ }^{3}$ Institute of Botany, Nucleus of Phycology, CEP 04301-902, São Paulo, SP, Brazil
}

\begin{abstract}
The phylogeny of the family Selenastraceae was investigated by light microscopy, 18S rDNA, $r b c L$ and ITS-2 analyses. Various morphological features traditionally used for species and genera identification were investigated. All selenastracean strains studied have naked pyrenoids within the chloroplast, except the genus Chlorolobion, which presented starch envelope. The molecular analyses showed that no morphological criterion considered so far is significant for the systematics of the Selenastraceae, but a set of features may be suitable to identify the genera Ankistrodesmus and Chlorolobion. Phylogenetic analyses showed the genera Monoraphidium, Kirchneriella and Selenastrum were not monophyletic and not distinguishable as separate genera. The polyphyly of the genus Selenastrum led to the description of two new genera, Curvastrum gen. nov and Messastrum gen. nov.
\end{abstract}

Key words: Ankistrodesmus, Chlorolobion, Kirchneriella, molecular systematics, morphology, phylogeny, Selenastrum

\section{INTRODUCTION}

Selenastraceae BLACKMAN \& TANSLEY 1903 (Chlorophyceae, Sphaeropleales) is a green algae family common in freshwater bodies all over the world, presenting a high morphological diversity (KRIENITZ et al. 2001). This family includes the most common members of phytoplankton in nearly all types of inland waters. They can produce mass developments in lakes, ponds, pools and rivers (Messyasz 2003; TAS \& GonUlol 2007). Although they commonly occur in freshwater habitats, some species tolerate moderate saline habitats as well, i.e. some taxa are reported from brackish and low saline areas of the Baltic Sea (PAnkow 1990). The Selenastraceae are valuable indicator organisms for ecosystem health, and several species of this family are regularly used as indicator species, e.g. in the frame of the European Water Framework Directive (MischKe \& KusBer 2009). The morphology of this group comprises a variety of shapes: from coccoid to elongated, cylindrical to fusiform, sickle-shaped to spirally curved, with sharp or rounded ends, where cell arrangements varies from the solitary to colonial forms (KOMÁREK \& FotT 1983; Korshikov 1987; KomÁrkovÁ-LegneROvÁ 1969; COMAS 1996; HiNDÁK 1977; HiNdÁK 1980; HiNdÁK 1984; HiNdÁK 1988; HindÁK 1990; SANT'ANNA 1984). Their reproduction is exclusively by autospore formation, in which the cytokinesis of the mother cell protoplasm gives rise to 2-4-8 young cells (KOMÁREK $\&$ Fотт 1983). The combination of cell size, shape, solitary or colonial lifestyle, the releasing process of the autospores and special habitat preferences, are considered to be species-specific (HINDÁK 1977; KOMÁREK $\&$ Fotт 1983). Based on these criteria, up to 100 species were described in various genera and included in this family (HindÁK 1977; Hindák 1984; KomÁreK \& FotT 1983; FAwley et al. 2006; Krienitz et al. 2011).

Since its description in 1903, the family Selenastraceae has passed by many taxonomic changes, being recognized as: Scenedesmaceae BoHLin 1904, Selenastraceae WeSt \& FrITSCH 1927, Ankistrodesmacaeae Korshikov 1953, Oocystaceae Bourrelly 1972, Chlorellaceae - Ankistrodesmoidea KomAREK \& FotT 1983. However, first studies in the $18 \mathrm{~S}$ rDNA of the 
commonly observed genera in this family, e.g. Ankistrodesmus, Selenastrum, Monoraphidium, Quadrigula, Podohedriella and Kirchneriella, show that they form a monophyletic group within the Chlorophyceae (FAWLEY et al. 2006; KRIENITZ et al. 2011; KRIENITZ et al. 2001), apart from other members of Scenedesmaceae (FAwLEY et al. 2006; KRIENitz et al. 2001), Oocystaceae [which is now placed within the Class Trebouxiophyceae (FriEdL 1995)] and Chlorellaceae (FrIEDL 1995; KRIENITZ et al. 2001). Since the onset of molecular phylogeny, several genera were excluded from the family due to their molecular traits, e.g., Closteriopsis was transferred to the Chlorellaceae and Hyaloraphidium is in fact a fungus (Luo et al. 2010; UstinOva et al. 2001).

Despite the monophyly of the family, the genera still need revision, since morphological features are usually not in accordance with molecular data (KRIENITZ et al. 2001; KRIENITZ et al. 2011). For example, defined genera cluster polyphyletic on different clades within the Selenastraceae, e.g. Selenastrum bibraianum (type species of Selenastrum), and Selenastrum gracile belong to different phylogenetic lineages based on 18S rDNA phylogeny (FAWLEY et al. 2006; KRIENITZ et al. 2001) but no taxonomic changes were made in the genus, since the authors suggested further studies with the family to ensure these findings.

Due to the difficulties in their identification and taxonomy, the current knowledge of species diversity and ecology of Selenastraceae is still poorly understood worldwide (FAWLey et al. 2006; Krienitz et al. 2001). In addition, previous studies were focused on temperate northern hemisphere isolates, whereas the molecular diversity of tropical Selenastraceae remains unknown.

Phylogenetic inference in green algae is mainly based on 18S rDNA sequences (BоотоN et al. 1998; BuchHeim et al. 2001; FAwley et al. 2006; Hegewald \& Hanagata 2000; Krienitz et al. 2011; Krienitz et al. 2003; KRIENITZ et al. 2001; LewIs 1997). Nevertheless, several studies have shown that the $18 \mathrm{~S}$ rDNA is in some cases too conserved to distinguish between closely related genera and species (Luo et al. 2010). Different studies take a second marker into account as well, to gain a higher resolution (RINDI et al. 2011). The gene $r b c L$ is being widely used mainly because of its higher variations and better resolution than the $18 \mathrm{~S}$ rDNA at lower taxonomic levels (FučíkOvá et al. 2011) and is also used as a DNA barcode in marine green macroalgae (SAUNDERS \& KUCERA 2010). The ITS-2 has proven to be a suitable marker for small scale phylogenies and it is commonly applied among species within the same genus (Bock et al. 2011b; Coleman 2003; Coleman 2007; COLEMAN \& VACQUIER 2002; Schultz et al. 2005; Young \& Coleman 2004) or for the resolution of closely related genera (LuO et al. 2010; Luo et al. 2011b). The highly divergent properties and the rapid evolution legitimate ITS-2 to discriminate closely related organisms, which exhibit nearly identical sequences in
rRNA genes (WoLf et al. 2013).

In response to the difficulty in accurately identifying Selenastraceae species worldwide, this study aimed to clarify the taxonomic status of some members of this algae family and contribute to the knowledge about their diversity. The present study is the first attempt to evaluate Selenastraceae combining morphology, gene sequences of $18 \mathrm{~S}$ rRNA and $r b c L$, and ITS-2 secondary structure.

\section{Material and Methods}

Algal cultures and microscopy. Forty five Selenastraceae strains were investigated (Table S2). The algal cultures were obtained from Freshwater Microalgae Culture Collection from Universidade Federal de São Carlos (CCMA - UFSCar, WDCM 835) and from an author personal collection (CB strains). All the strains were grown in WC medium (GuILlARD \& LoRENZEN 1972) and maintained at of $23 \pm 1$ ${ }^{\circ} \mathrm{C}$, under photoperiod 12/12 hours light/dark, and luminous intensity of $\sim 200 \mu \mathrm{mol} . \mathrm{m}^{-2}$. $\mathrm{s}^{-1}$.

The whole life cycles of cultured strains were examined using an Axioplan 2 Imaging Zeiss or Nikon Eclipse E600 light microscope with differential interference contrast. Micrographs were taken using an AxioCam with software AxioVision 4.6 (Carl Zeiss Group, Oberkochen, Germany) and a Nikon digital camera DS-Fil with Nikon software NIS-Elements D (Nikon Corporation, Tokyo, Japan). The algal strains were identified according to the published keys (Korshikov 1987; KomÁreK \& FotT 1983; KomÁrkovÁLegnerová 1969; Comas 1996; HindÁK 1977; HindÁk 1980; HindÁk 1984; HindÁk 1988; HindÁK 1990; SANT'AnNa 1984).

Before Scanning Electron Microscopy (SEM) and Transmission Electron Microscopy (TEM) cells were fixed in $2.5 \%$, glutaraldehyde in culture medium (HEGEWALD et al. 1994) for 24 hours at $-5^{\circ} \mathrm{C}$, and dehydrated as follows. The cells were washed three times with culture medium and dehydration series was taken in a graded acetone series: 20, 35, $50,70,90 \%$ (twice) for 15 minutes each step, and 100\% kept overnight. Samples were washed three times with culture medium and postfixed with $1 \%$ osmium tetroxide for 2 hours.

For SEM, a Critical Point Dryer (BAL-TEC 030, Germany) was used at $80-90$ bars and $30-34{ }^{\circ} \mathrm{C}$. The samples were placed on a gold-palladium-coater (High Resolution Ion Beam Coater Model 681, Germany) and then 2 depositions of palladium were made $( \pm 1 \mathrm{k} \AA)$. SEM images were taken with ESEM Quanta 400 FEG (FEI, The Netherlands).

TEM was performed according to KRIENITZ et al. (2011) with infiltration in epon. Thin sections were prepared on a Reichert UltraCut S (Reichert Inc., Depew, NY, USA), with no poststain and examined in a Hitachi S-4000 Scanning Electron Microscope (IMCES-Imaging Center Essen).

DNA extraction, PCR and sequencing. For DNA extraction, the algae cultures were grown in the conditions described above for microscopy analyses. The cell suspension was centrifuged at $16.000 \times \mathrm{g}$ for 10 minutes and the pellet stored at $-80{ }^{\circ} \mathrm{C}$ until the next step. The cells were disrupted using glass beads (150-212 $\mu \mathrm{m}$, Sigma-Aldrich), vortex briefly, and extracted using Invisorb ${ }^{\circledR}$ Spin Plant Mini (STRATEC Biomedical AG; Germany) or My-Budget DNA 
Mini Kit ${ }^{\circledR}$ (Bio-Budget Technologies GmbH; Krefeld; Germany).

PCR amplification was carried out using established target-specific primers and some primers proposed in this study. For $18 \mathrm{~S}$ rDNA, the primers used were $18 \mathrm{SF} 1$ (Katana et al. 2001), 1F, 300F, 528F, 690F, 920F, 1055F, 1400F, 920R, 1200R, 1520R (Huss et al. 1999), 18SR1 (5 - TGATCCTTCTGCAGGTTCACCTA - 3') modified from KATANA et al. (2001). Four new primers were designed for the $r b c \mathrm{~L}: r b c \mathrm{~L} 320 \bmod \left(5^{\prime}\right.$ - TATTYGAASAAGGTTCWGTWAC- 3', modified from RINDI (2008), Selenastraceae $r b c L$ F (5' - CGYTACAAAGGDCGTTGYT - 3'), $r b c L$ Orb modified ( $5^{\prime}$ - CTGGNGCRTTACCCCAAGG - 3'), modified from PAŽoutová (unpublished), and Selenastraceae $r b c L$ R (5' - RTTACCCCAWGGGTGHCCTA - 3'). These proposed primers were used in association with the following published primers, $r b c L 1, r b c L$ 1181, 1421 (NozAKI et al. 1995), rbcL 320 (RINDI et al. 2008), rbcL RH1 (MANHART 1994), $r b c L 1385$ (McCourt et al. 2000), and $r b c L$ ORB (Pazoutova unpublished). For ITS-2 the primers used were 1420F (Rogers et al. 2006), NS7m and LR1850 (An et al. 1999) and ITS055R (MARIN et al. 1998). For more details about primers, see Table S3 (supplementary material). The PCR amplifications for $r b c L$ gene were performed using the following reaction conditions: $95{ }^{\circ} \mathrm{C}$ for 5 min followed by 25 cycles, each including $1 \mathrm{~min}$ at $95^{\circ} \mathrm{C}, 1 \mathrm{~min}$ at $52^{\circ} \mathrm{C}$, and $2 \mathrm{~min}$ at $72{ }^{\circ} \mathrm{C}$ with Taq DNA Polymerase QIAGEN ${ }^{\circledR}$ or DreamTaq DNA Polymerase Thermo Scientific ${ }^{\circledR}$. 18S rDNA PCR amplifications were conducted according to KATANA et al. (2001) and KRIENITZ et al. (2011). ITS-2 PCR amplifications were performed according to Bock et al. (2011). Each PCR product was electrophoresed in a $1 \%$ agarose gel, stained with ethidium bromide.

Purification of the PCR products was conducted using the polyethylene glycol protocol (PEG) according to Rosenthal et al. (1993). The PCR products were sequenced by Macrogen Inc. (ABI 3130-Genetic-Analyzer, Applied Biosystems GmbH, Darmstadt, Germany) with the same primers used for amplification. Part of the genomic DNA is stored at the Phycology Lab - UFSCar, and Department of Biodiversity - University Duisburg-Essen.

Twenty three new $18 \mathrm{~S}$ rDNA sequences, 34 new $r b c L$ sequences and 8 ITS -2 new sequences were amplified and obtained on this study, totalizing 65 new entries in GenBank (National Center for Biotechnology Information [NCBI], http://www.ncbi.nlm.nih.gov/). The whole dataset used for phylogenetic analyses with accession numbers are reported in Table S2, including 29 reference sequences acquired from GenBank

Phylogenetic analyses. Sequences were manually aligned using Align - Manual Sequence Alignment Editor (HePPERLE 2004). For the phylogenetic analyses, two different datasets were prepared. The $r b c L$ analyses contained a dataset of 40 sequences with 767 base positions. For the $18 \mathrm{~S}$ rDNA analyses, 46 sequences with 1511 base positions were acquired. The two genes (18S rDNA and $r b c L$ ) were analyzed separately, both in maximum likelihood (ML) on Treefinder (Јовв 2008), distance (neighbor joining; NJ) and maximum parsimony (MP) using PAUP* (portable version 4.0b10) (SwoFFORD 2002). For ML and Bayesian analyses, the evolutive model for both genes (18S rDNA and $r b c L$ ) (GTR[Optimum, Empirical]: G[optimum]:5) was applied as suggested by $\mathrm{Mr}$ Modeltest (NYLANDER 2004), with tree sampling every 100 generations. The confidence of the tree topology was tested by calculating 1000 bootstrap values for NJ, MP, ML criteria. For all datasets, Bayesian analyses were performed using MrBayes version 3.1. (HuelsenbecK \& Ronquist 2001). Two runs with four chains of Markov chain Monte Carlo (MCMC) iterations were performed ( 3 million generations for $r b c L$ and 8 million generations for $18 \mathrm{~S}$ rDNA). The stationary distribution was assumed when the average standard deviations of split frequencies between two runs were lower than 0.01 and Tracer V1.4 (RAmbaut \& DRummond 2007) was used to check the stationary phase and to identify an appropriate burn-in value. The first $25 \%$ of the calculated trees were discarded as burn-in. 50\% majority-rule consensus trees were calculated for posterior probabilities (PP). The trees were edited using TreeGraph 2 (StÖver \& MüLler 2010). Previous publications indicated that Bracteacoccus (KRIENITZ et al. 2001) and Pediastrum (FučíkovÁ et al. 2014) members were suitable as an outgroup for the phylogeny of Selenastraceae.

ITS-2 secondary structure prediction. The ITS-2 model for Scenedesmus, proposed by van Hannen et al. (2002), was used as a template and adapted by hand. The secondary structure was obtained using the RNAfold Webserver (GRUBER et al. 2008) where the minimum free energy (MFE) of the secondary structure of single sequences and the equilibrium base-pairing probabilities were predicted. The RNA secondary structures were visualized with Pseudoviewer 3 (BYUN \& HAN 2009).

\section{Results}

\section{Genera and species descriptions}

\section{Messastrum gen. nov. T. S. GaRCIA}

Description: Green, planktonic microalgae. Narrow, fusiform to semilunate cells, ends gradually pointed, arcuate. Colonies with $2-4-8$ or multi irregularly arranged cells, mostly with the convex side towards the center of the colony. One parietal chloroplast, containing a pyrenoid, no starch cover observed.

Asexual reproduction by autosporulation (24-8 autospores per sporangium), sexual reproduction not known. An unseparated fragment of the mother cell membrane remains and is covered by a thin mucous layer. Cells single or on 2-4-8 or multi-celled colony formation. Cells often single celled in culture. A diffuse thin layer of mucilage is often concentrated as a ring on the middle of the cells on both colonies and free individuals. Genus differs from other genera in the Selenastraceae based on differences in $18 \mathrm{~S}$ rDNA and $r b c L$ gene sequences.

Typus generis: Messastrum gracile comb. nov. Etymology: From the Latin mess (= mess) and astrum (= star). 
Messastrum gracile comb. nov. (REINSCH) T. S. GARCIA

Synonym: Ankistrodesmus gracilis (ReInsch) KorshiKov 1953, Selenastrum westii G.M.Sмiтн 1920, Dactylococcopsis pannonicus HORTOBÁGYI 1943.

Basyonym: Selenastrum gracile ReINSCH 1866: 65, pl. IV: Fig. III.

Description: Cells narrow, fusiform to semilunate, ends gradually pointed, arcuate. Planktonic, solitary or 2-4-8 or multi-celled colonies with irregularly arranged cells, mostly with the convex sides towards the center of the colonies. Reproduction by autospore formation, where the sporangium gives rise to 2-4-8 young cells, with parallel or zigzag orientation. Pyrenoid without starch cover, observed just under TEM. One parietal chloroplast. Cell wall covered by a diffuse thin layer of mucilage on both colonies and free individuals. A diffuse thin layer of mucilage is often concentrated as a ring on the middle of the cells on both colonies and free individuals. Cells19-55 × 1-6 $\mu \mathrm{m}$, distance between the opposite cell ends 6-34 $\mu \mathrm{m}$.

Holotype: Selenastrum gracile ReInsch 1866: 65, pl. IV: Fig. III.

Epitype (designated here): A formaldehyde fixed sample of strain CCMA-UFSCar 622 is deposited at the Botanical Institute at São Paulo, Brazil, under the designation SP 469319.

Isotype: Material of the authentic strain CCMA-UFSCar 622 (Fig. 1), maintained at the Culture Collection of Freshwater Microalgae, Federal University of São Carlos, São Carlos, Brazil.

Etymology: The species epithet is based on a morphological feature, "thin, slender", kept on this nomenclatural change.

Notes: Epitype isolated from a pond in Conchas, in the country side of the state of São Paulo, in August 2013. More strains were collected inside the state of São Paulo (CCMA-UFSCar 5 and CCMA-UFSCar 470 (For GPS see Table S2).

\section{Curvastrum gen. nov. T. S. GaRCIA}

Description: Green, planktonic microalgae. Narrow, fusiform to semilunate cells, ends gradually pointed, arcuate. Colonies with 4 irregularly arranged cells. One parietal chloroplast, containing a pyrenoid without starch cover, observed just under TEM.

Asexual reproduction by autosporulation (four autospores per sporangium), sexual reproduction not known. Cells single or on 4-celled colony formation. Cells often single celled in culture. Cell wall covered by a diffuse thin layer of mucilage on both colonies and free individuals. Genus morphologic similar to Messastrum, distinguishing for the numbers of cells on colony and $18 \mathrm{~S}$ rDNA, ITS-2 rDNA and $r b c L$ sequences.

Typus generis: Curvastrum pantanale sp. nov. Etymology: From the Latin curvus (= curved) and astrum, (= star).
Curvastrum pantanale sp. nov.T. S. GARCIA

Description: Cells narrow, fusiform to semilunate, ends gradually pointed, arcuate. Planktonic, solitary or 4-celled colonies with 4 irregularly arranged cells, mostly with the convex sides towards the center of the colonies. Reproduction by autospore formation, where the sporangium gives rise to 4 young cells, with zigzag orientation.Pyrenoid without starch cover. One parietal chloroplast. Cell wall covered by a diffuse thin layer of mucilage on both colonies and free individuals. Cells 8-21 $\times 1.9-3.5 \mu \mathrm{m}$, distance between the opposite cell ends: $4-14 \mu \mathrm{m}$.

Holotype: A formaldehyde fixed sample of this strain is deposited at the Botanical Institute at São Paulo, Brazil, under the designation SP 469320.

Iconotype: our figure number 3-4.

Isotype: Material of the authentic strain CCMA-UFSCar 350, maintained at the Culture Collection of Freshwater Microalgae, Federal University of São Carlos, São Carlos, Brazil.

Type locality: Isolated from a water fountain used as a supply for animals on Pantanal (Table S2), a Brazilian wetland, in October 2011. GPS 19¹7'59.0"S $55^{\circ} 47^{\prime} 45.0^{\prime \prime} \mathrm{W}$.

Etymology: The species epithet was derived from the place of origin of the first isolate of this genus, "Pantanal", which means "great Swamp".

Notes: Also collected inside the state of São Paulo (CCMA-UFSCar 608).

Selenastrum bibraianum (REINSCH) KORSHIKOV 1953 Synonym: Ankistrodesmus bibraianus (REINSCH) KoRshiKov 1953 Basyonym: Selenastrum bibraianum ReinsCH 1866: 65, pl. IV: Fig. II.

Description: Cells narrow, fusiform to semilunate, ends gradually pointed, arcuate. Planktonic, solitary or 2-4-8 or multi celled colonies with regularly arranged cells, mostly with the convex sides towards the center of the colonies, by their convex side. Reproduction by autospore formation, where the sporangium gives rise to $2-4-8$ young cells, with parallel or zigzag orientation. One parietal chloroplast. Cell wall covered by a strong layer of mucilage on colonies. A diffuse thin layer of mucilage is often concentrated as a ring on the middle of the cells on colonies and free individuals. Cells $16-40 \times 2-8 \mu \mathrm{m}$, distance between the opposite cell ends $2-20 \mu \mathrm{m}$.

Holotype: Selenastrum bibraianumReINSCH 1866: 65, pl. IV: Fig. II.

Epitype (designated here): A formaldehyde fixed sample of strain CCMA-UFSCar 47 is deposited at the Botanical Institute at São Paulo, Brazil, under the designation SP 469321.

Isotype: Material of the authentic strain CCMA-UFSCar 47, maintained at the Culture Collection of Freshwater Microalgae, Federal University of São Carlos, 

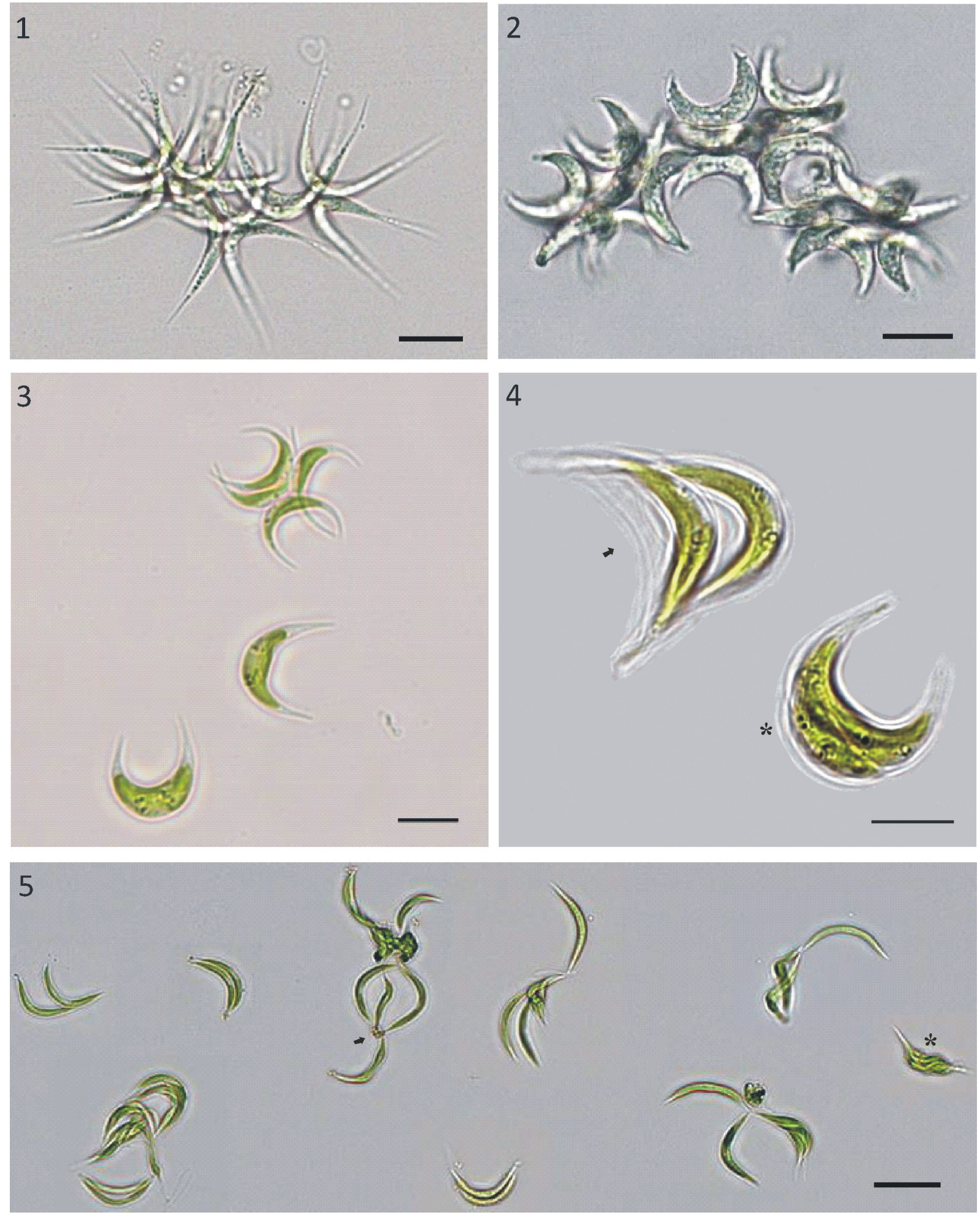

Figs 1-5. (1) Messastrum gracile, original picture of strain CCMA-UFSCar 622 showing a frontal view of colony; (2) Selenastrum bibraianum, original picture of strain CCMA-UFSCar 125 showing a frontal view of colony; (3-4) Curvastrum pantanale, (3) original picture of strain CCMA-UFSCar 350, showing free cells and colony, (4) original picture of strain CCMA-UFSCar 350, showing cells in autospore liberation presenting a cell wall remnant (arrowhead) and protoplasm cleavage (star); (5) Ankistrodesmus arcuatus, original picture of strain CCMA-UFSCar 24, showing free cells and colony. Note autospore formation (star) and mucilaginous lump (arrowhead). Scale bar $10 \mu \mathrm{m}$.

São Carlos, Brazil.

Etymology: no reference.

Notes: Epitype - isolated from a reservoir in São Car- los (Represa do Monjolinho), in the country side of the state of São Paulo, in November 2008. More strains were collected inside the state of São Paulo (CCMAUFSCar 125 and CCMA-UFSCar 630), two strains 
were isolated from Germany (CB 2009/39 and CB 2009/43) and one from Sweden (CB 2012/47) (Table S2).

\section{Ankistrodesmus arcuatus KorshIKov 1953}

Synonym: Monoraphidium arcuatum (KoRSHIKOv) HINDÁK 1970: 24, Figs 19, 10, Ankistrodesmus pseudomirabilis KoRSHIKOv 1953: 297, Fig. 258 a-f, Ankistrodesmus sabrinensis Belcher \&Swale 1962: 131, Fig. 1:H.

Basyonym: Ankistrodesmus arcuatus KonshIKov 1953: 296, Fig. $257 \mathrm{a}, \mathrm{b}$.

Emend diagnosis: Cell solitary or in colonies, fusiform, narrow or acute at the ends, arched or curved. Four celled colony where cells are arranged by one end attached in mucilage. Presence of mucilage. One parietal chloroplast. Reproduction by autospore formation, where the sporangium gives rise to 4-8 young cells, with parallel orientation. Mother cell wall ruptures along the whole length to autospore liberation. Pyrenoid without starch cover, observed just under TEM analyses. Dimensions: $26-60 \times 0.8-4.4 \mu \mathrm{m}$, distance between the cell ends: $30 \mu \mathrm{m}$.

Holotype: Ankistrodesmus arcuatus KORSHIKOV 1953: 296, Fig. 257a, b.

Epitype (designated here): A formaldehyde fixed sample of strain CCMA-UFSCar 24 is deposited at the Botanical Institute at São Paulo, Brazil, under the designation SP 469322.

Isotype: Material of the authentic strain CCMA-UFSCar 24 (Fig. 5), maintained at the Culture Collection of Freshwater Microalgae, Federal University of São Carlos, São Carlos, Brazil.

Etymology: The species epithet is based on a morphological feature, "arched", kept on this nomenclatural change.

Note: According to the original diagnosis (KoRshiKov 1953), the author adds a suggestion that the cells may belong to decomposed colonies of Messastrum graci$l e$, differing only by the absence of mucus. KOMÁRKOVÁ-LEGNEROVÁ (1969) considered a possible colony formation and mucilage presence but did not make a nomenclatural recombination. Epitype: isolated from Broa Reservoir, Itirapina, in the country side of the state of São Paulo, in 1979 (Table S2).

Light microscopy. This section is focused on morphological traits that conducted to species differentiation based on light microscopy. For identification keys and diacritical features of established species see Material and methods. A summary is provided in Table S1.

Seven strains were analyzed based on light microscopy which match the morphological description for the genus Selenastrum according to REINSCH (1866) and KomÁReK \& Fotт (1983). The strains CB 2009/39, CB 2009/41, CB 2009/43, CB 2012/47, CCMA-UFSCar 47, CCMA-UFSCar 125 and CCMA-UFSCar 630 had similar cell shape, with narrow and fusiform to semilunate isopolar cells, $2-4-8$ autospores per sporangium, mother cells ruptures in the meridian part with 4-8 autospores per sporangium. All strains exhibited a great mucus layer a parenthesis both in colony and in solitary cells.

Strains CCMA-UFSCar 47, CCMA-UFSCar 125, CCMA-UFSCar 630, CB 2009/39, CB 2009/41 and $\mathrm{CB} 2012 / 47$ differed only slightly in their morphology. They resembled the morphological criteria for Selenastrum bibraianum with fusiform to semilunate cell shape, lengths of $18-40$ long $\times 2-8 \mu \mathrm{m}$ large. They occured in big colonies with up to 19 cells and with an arcuated chain of cells, regularly arranged in colony. Strains CCMA-UFSCar 5, CCMA-UFSCar 470, CCMA-UFSCar 622, CB 2009/3 and CB 2009/35 had similar morphological features as the strains of $S$. bibraianum but differed in their colony formation. The morphological criteria to the newly combined Messastrum gracile was the fusiform to semilunate cell shape, lengths of 19-55 long $\times 1-6 \mu \mathrm{m}$ large. They frequently showed big colonies with an arcuated chain of cells, irregularly arranged in this case, where colonies up to 11 cells were observed. The strains that belong to the new species Curvastrum pantanale (CCMA-UFSCar 350 and CCMA-UFSCar 608) exhibited colonies with no more than 4 cells, irregularly arranged in colony, which lengths observed were of 8-21 long $\times 2-3.5 \mu \mathrm{m}$ large (Fig. 8a).

Cells with fusiform and isopolar cells shape (solitary cells and in colony), autospores arranged in parallel and mother cell wall remnants cone-shaped could be observed in the strains CB2009/9, CB 2012/3, CB2012/6, CB2012/29, CCMA-UFSCar 24, CCMA-UFSCar 277, CCMA-UFSCar 278, CCMAUFSCar 423, CCMA-UFSCar 593, CCMA-UFSCar 611. Due to the characteristics in morphological keys, these strains were identified as members of the genus Ankistrodesmus. The identified and studied species were: Ankistrodesmus spiralis (TURNER) LEMMERMANN (CB2012/29; colonies with central twisted bundles, mucilage only observed around colonies); Ankistrodesmus stipitatus (CHODAT) KOMÁRKOVÁ-LEGNEROVÁ (CCMA-UFSCar 277, CCMA-UFSCar 278 cells frequently arranged in parallel in free floating fascicular colonies, some cells were attached to the walls of the glass tubes, producing basal mucilage on their ends, autospores seemed to be attached to each other by the middle of the cell even before the mother cell rupture); Ankistrodesmus fusiformis CORDA (CB 2012/6, CCMA-UFSCar 423, CCMA-UFSCar 611, CCMAUFSCar 593; cruciform or stellate colonies joined by a central mucilaginous area); Ankistrodesmus fasciculatus (LundBerg) KomÁRKOvÁ-LegnerovÁ (CB 2012/3; presented 2-4 celled colonies connected to each other by their convex side, revealing a fasciculate shape, surrounded by a mucus layer. Ankistrodesmus sigmoides had sigmoid colony formation. Ankistrodesmus arcuatus (Korshikov) HindÁk (CCMA-UFSCar 24) arcu- 


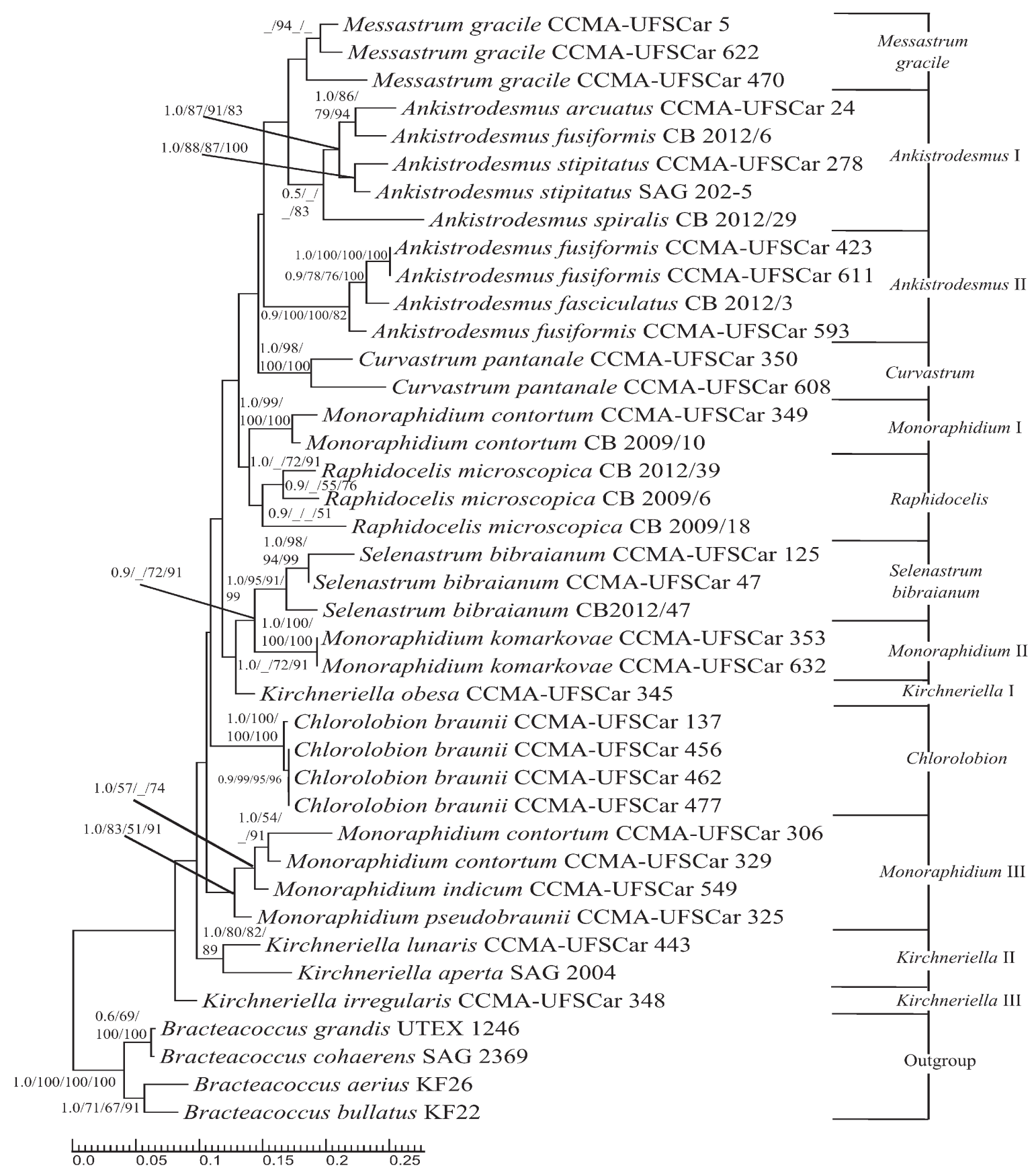

Fig. 6. Maximum-likelihood (ML) phylogenetic tree inferred from $r b c L$ gene sequences of some members of Selenastraceae. Support values correspond to Bayesian PP (Posterior Probability), ML BP (Bootstrap), MP (Maximum Parsimony)BP, NJ (Neighbor-Joining)BP. Hyphens correspond to values $<50 \%$ for BP and $<0.95$ for PP. Scale represents the expected number of substitutions per site. Strain numbers used as mentioned in Table S2.

ated cells were arranged frequently in parallel in free floating fascicular colonies.

Chlorolobion braunii (NÄGELI) KOMÁREK (CCMA-UFSCar 137, CCMA-UFSCar 455, CCMAUFSCar 462 and CCMA-UFSCar 476) had fusiform, heteropolar to isopolar cells, showing some cell asymmetry which lengths observed were of 13-52 long $\mathrm{x}$ 3-8 $\mu \mathrm{m}$ large. It was observed starched pyrenoid on this species, with elliptic to rounded shape. Many cells were attached to the walls of the glass tubes, producing basal mucilage on their ends, as in A. stipitatus. The autospore formation was peculiar and very discernible in this species.

Raphidocelis microscopica (NYGAARD) MARvan, KomÁreK et Comas (CB 2009/6, CB 2009/18 and CB 2012/39) formed colonies with mucilage and very small cells (3-5 long $\times 1-2 \mu \mathrm{m}$ large) irregularly distributed on the colony.

All Kirchneriella SCHMidLe species were similar in cell shape and in the colony morphology, varying on cell size and on the next exposed features. Kirchneriella pseudoaperta KOMÁREK (CCMA-UFSCar 


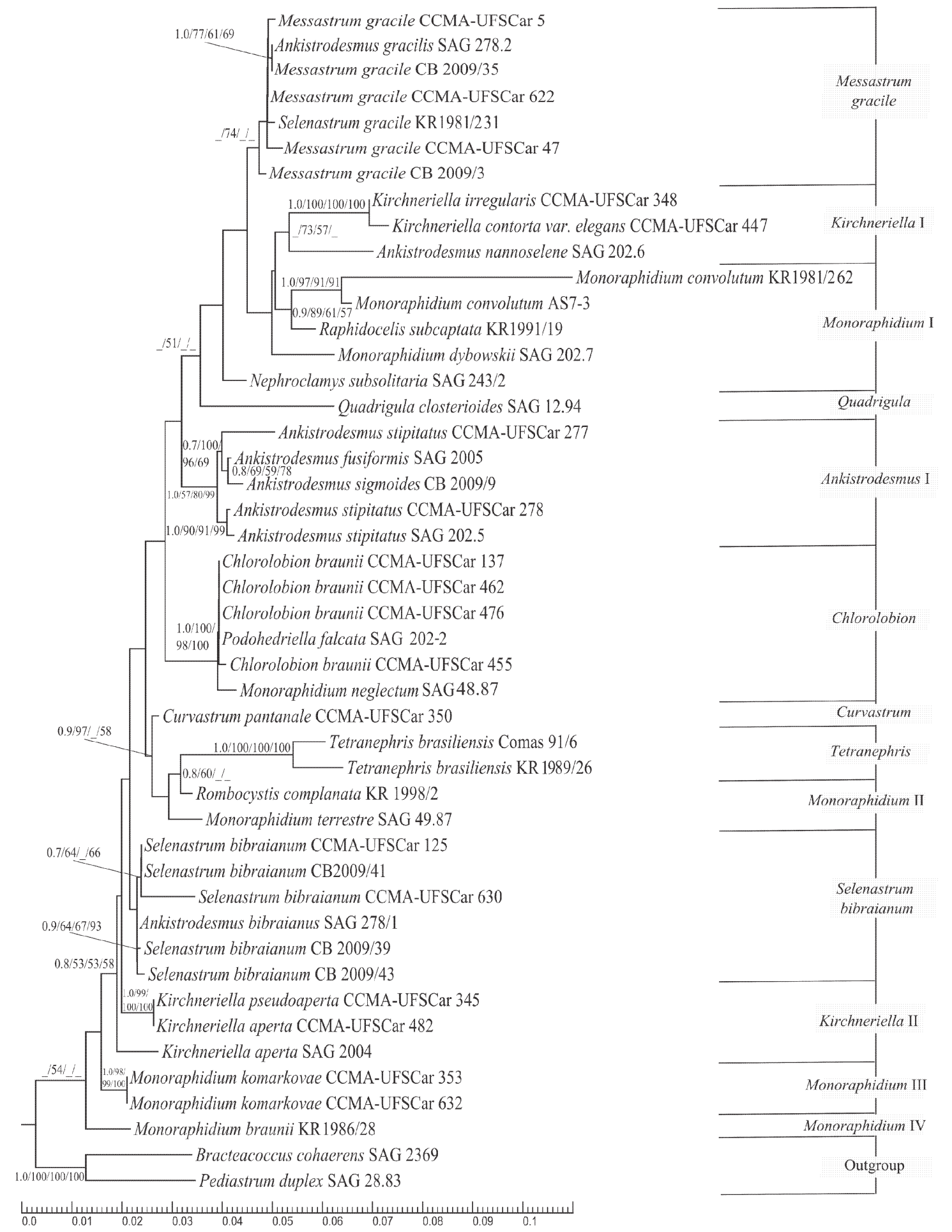

Fig. 7. Maximum-likelihood (ML) phylogenetic tree inferred from 18S rDNA gene sequences of some members of Selenastraceae. Support values correspond to Bayesian PP (Posterior Probability), ML BP (Bootstrap), MP (Maximum Parsimony) BP, NJ (Neighbor-Joining)BP. Hyphens correspond to values $<50 \%$ for BP and $<0.95$ for PP. Scale represents the expected number of substitutions per site. Strain numbers used as mentioned in Table S2.

346) presented visible pyrenoid under LM, and cell size were 1.6-9.6 long $\times 2.4-4.2 \mu \mathrm{m}$ large. Mucilage was exhibited when in colony, where mainly $4-$ celled colonies were observed. Some cells kept connected to each other before leaving the mother cell. Kirchneriella obesa (WESt) WeSt etWest (CCMA-UFSCar 345) presented mucilage when in colony and solitary cells were bigger in size than the colony living ones. Cell size varied from 6-16 long $\times 2-9.5 \mu \mathrm{m}$ large. Kirchneriella aperta TEILING (CCMA-UFSCar 482) exhibited mucilage when in colony but not when in solitary cells, where cell size observed was $6-12$ long $\times 12 \mu \mathrm{m}$ large. 

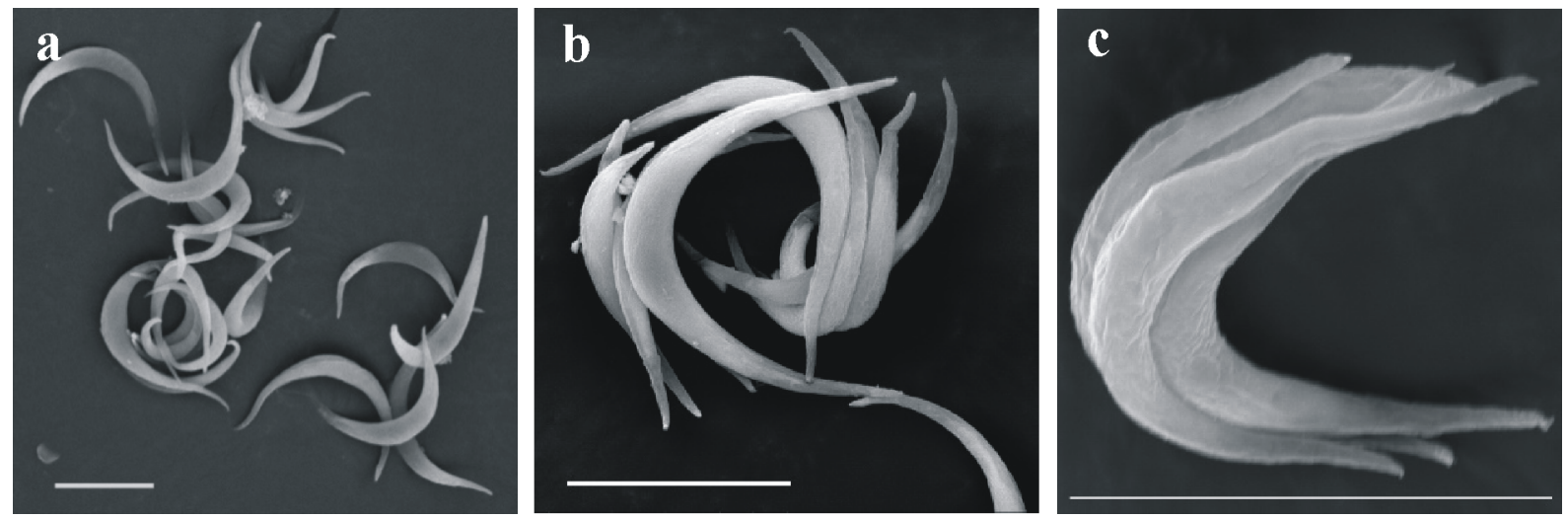

Fig. 8. Scanning electron micrographs of Curvastrum pantanale (CCMA-UFSCar 350) in culture: (a) typical colony formation, (b) young cells detaching from each other, (c) young cells, note the autospores position. Scale bar, $10 \mu \mathrm{m}$.

Kirchneriella lunaris (KIRCHNER) MöBIUS (CCMAUFSCar 443) had acute cell apex, with solitary cells bigger than the colonies one, always presenting pyrenoids and with cell dimensions from 4-15 long to 1.2-2.8 $\mu \mathrm{m}$ large. Kirchneriella contorta var. elegans (Playfair) KomÁrek (CCMA-UFSCar 447) had circular, crescent-shaped to sigmoid cells with rounded cell apex, with cell lengths from $6-8$ long to $2 \mu \mathrm{m}$ large. Kirchneriella irregularis (SMITH) KorSHIKOv (CCMAUFSCar 348) cells were fusiform to strongly twisted, very small in size (from 6-21 long to 3-6 $\mu \mathrm{m}$ large) and without mucilage.

Genus Monoraphidium KomÁRKOvÁ-LeGNEROVÁ always presented solitary and pyrenoid-less cells. Monoraphidium komarkovae NyGAARD (CCMAUFSCar 353 and CCMA-UFSCar 632) had very long and thin cells (from 25-182 long to 1.4-3.5 $\mu \mathrm{m}$ large), without mucilage. Monoraphidium contortum (ТнURET) KomÁRKOVÁ-LEgnerovÁ (CCMA-UFSCar 306, CCMA-UFSCar 329, CCMA-UFSCar 349 and CB 2009/10) presented strongly twisted cells (from 7-40 long to 1-5.2 $\mu \mathrm{m}$ large), with basal mucilage joining young cells after autospores liberation, like in $A$. stipitatus. Monoraphidium pseudobraunii (BELCHER et Swale) Heynig (CCMA-UFSCar 325) showed slightly heteropolarity, with no mucilage and 2 autospores per sporangium, with cells dimensions from 8-25 long to 1-2.5 large. Monoraphidium indicum Hindák (CCMA-UFSCar 549) cells were c-shaped to twisted (from 120-260 long to 3-5 $\mu \mathrm{m}$ large), with two autospores per sporangium and the mother cell wall was constantly found in culture.

In our study, except for Chlorolobion braunii (NäGELI) KomÁreK, all Selenastracean taxa studied had naked pyrenoids (without starch envelopes), both observed by LM or TEM.

\section{TEM microscopy}

The micrographs of members of the genera Ankistrodesmus, Monoraphidium and Curvastrum showed similarities among the studied strains, CCMA-UFS-
Car 24, CCMA-UFSCar 349 and CCMA-UFSCar 350. A large parietal and cup-shaped chloroplast was a typical feature between the observed strains (as seen on Fig. 9, d; Fig.10 b and e). The parietal chloroplast was filled with a large number of thylakoids situated in parallel to the cell wall (Fig.9, c-e; Fig.10, b, d, e). In addition, some polyphosphate vacuoles (Fig.9, a, c; Fig.10, b, d, e) were found on cells on stationary phase and often some lipid drops (Fig.9, a, b; Fig.10, d). The nucleus could be observed at the opposite direction of the pyrenoid (Fig.9, d, e; Fig.10, a, b, e) and, in between them, there is a dictyosome (Fig. 10c). Mitochondria (Fig.9, c, e) was observed at the inner surface of the chloroplast.

\section{Phylogenetic analyses}

Representatives of Selenastraceae were included in our rbcL (Fig. 6) and 18S rRNA gene sequence analyses (Fig. 7). Due to the low support of some internal branches in both phylogenies, the relationships among some lineages were not clearly resolved. However, some well-supported clades can be identified in both trees: (i) Selenastrum gracile, (ii) Selenastrum bibraianum, (iii) Raphidocelis, (iv) Curvastrum pantanale nov. gen. et. sp., (v) Kirchneriella, (vi) Chlorolobion (including Podohedriella falcata on the 18S rDNA tree), (vii) Ankistrodesmus, (viii) Monoraphidium. For Tetranephris, Quadrigula, Rhombocystis, Nephrochlamys, one clade for each genera was obtained on the $18 \mathrm{~S}$ rDNA tree, with no $r b c L$ sequences for them. The major clades resolved in our trees correspond well to the main genera traditionally included in Selenastraceae, that are, Ankistrodesmus and the distinguishable species of genus Selenastrum gracile and Selenastrum bibraianum (ReInsch) Korshikov. Due to the different number of strains inside $18 \mathrm{~S}$ rDNA and $r b c L$ trees, different results were obtained for some genera such as, Monoraphidium, Raphidocelis and Kirchneriella.

$R b c L$ phylogenetic analyses (Fig. 6) showed Selenastrum gracile (syn. Ankistrodesmus gracilis) strains closely related to Ankistrodesmus (Ankistrodes- 
mus clade). 18S rDNA phylogeny (Fig. 7) reveal $A n$ kistrodesmus distributed in two clades: Ankistrodesmus nannoselene SKUJA (KF673373) (Kirchneriella I) and Ankistrodesmus fusiformis (type species, Ankistrodesmus I). Selenastrum gracile strains (Selenastrum gracilis clade) (syn. Ankistrodesmus gracilis) and Selenastrum bibraianum (syn. Ankistrodesmus bibraianum) were placed on two different clades on both phylogenetic analyses.

Therefore some strains were only represented in one of the interfered phylogenies, which were, in general, congruent (see Figs. 6-7). The $r b c L$ proved to be a difficult gene to amplify in Selenastraceae.

Strains with the Selenastrum-like morphology

\section{a}
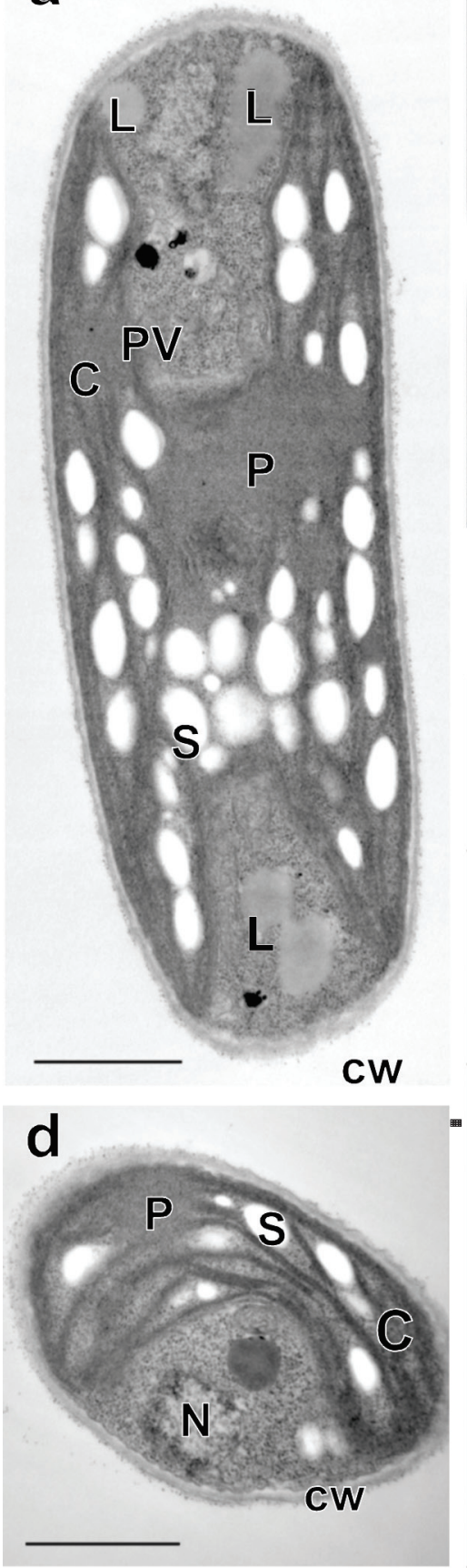
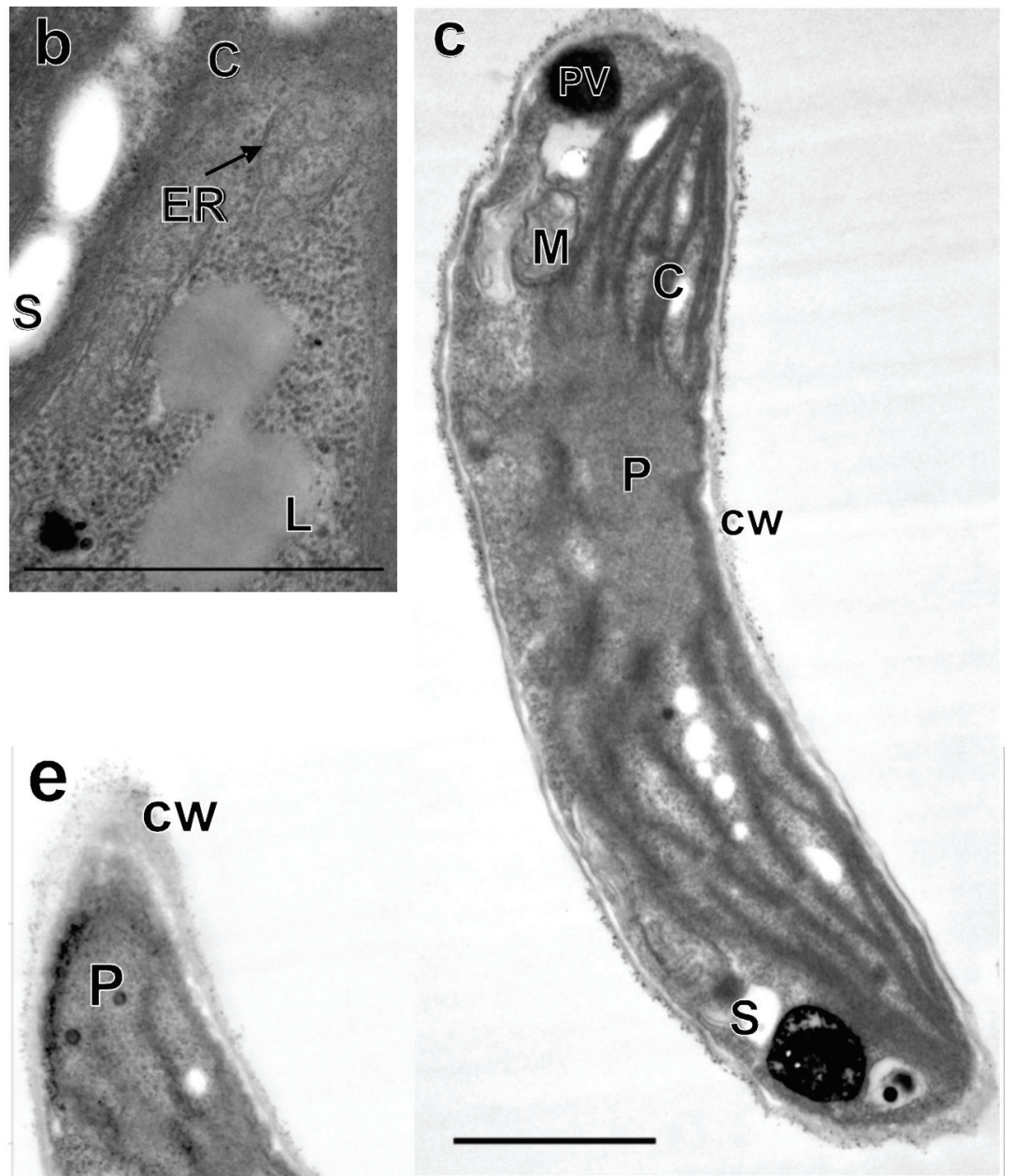

CW

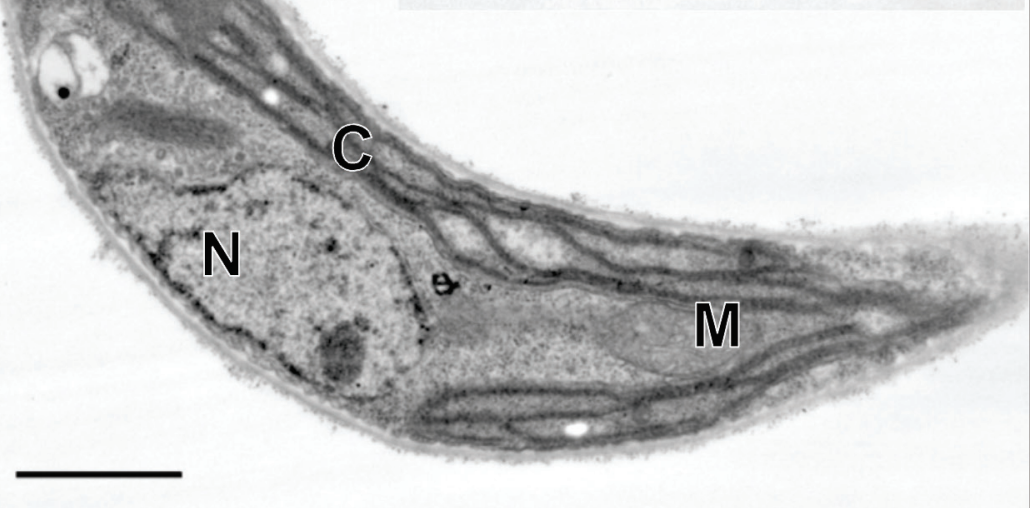

Fig. 9. Transmission electron micrographs of Curvastrum pantanale (CCMA-UFSCar 350) in culture [key to labeling: (CW) cell wall, (C) chloroplast, (D) dictyosome, (ER) endoplasmic reticulum, (L) lipid drop, (M) mitochondrion, (N) nucleus, (P) pyrenoid, (PV) polyphosphate vacuole, (S) starch grain]: (a) longitudinal section, cell presenting lipid drops, polyphosphate vacuoles (arrowhead), chloroplast penetrated with starch grains, and a central pyrenoid; (b) detail of figure a, where an endoplasmic reticulum (arrowhead) can be observed; (c) longitudinal section; cell presenting polyphosphate vacuoles on both cell apexes, mitochondria, chloroplast filled with starch grains and a central pyrenoid; (d) cross section; chloroplast containing starch grains and a pyrenoid situated at the left, a central nucleus can be observed; (e) longitudinal section; mature cell containing a central nucleus, mitochondrion and pyrenoid (upper part). All the cell content is surrounded by a cell wall. Scale bar $1 \mu \mathrm{m}$. 
(M. gracile, $C$. pantalale and $S$. bibraianum; details see section morphology) form three separate clades in both analyses with weak statistical support, except for the Curvastrum-clade within the $r b c L$ phylogeny which had high statistical support in all analyses (1.0 for BI; 98 BS for ML; 100 BS for NJ and MP).

Morphologically similar to Selenastrum and Messastrum, the fusiform to semilunate cells of Curvastrum were organized in colonies with no more than 4 irregularly arranged cells (see description). The irregularly arranged cells in Curvastrum pantanale (CCMA-UFSCar 350) formed its colony (Fig. 3, 1.8a), where cells were grouped in a loose fascicle arrange- ment (Fig. 8b) and presented parallel arrangement of autospores (Fig. 8c). The likeness to Messastrum was distinguished by molecular data (18S rDNA and $r b c L$ sequences). ITS-2 Secondary structure analyses demonstrated that strains of the type species Curvastrum pantanale (CCMA-UFSCar 350) when compared to another strain belonging to the same species (CCMA-UFSCar 608) differed from each other in 5 base changes, demonstrating intraspecific variations, with $2 \mathrm{CBC}$ on helix II and 1 on helix III (for ITS-2 secondary structure see Supplementary Fig. A-D). The phylogenetic inference of $r b c L$ (Fig. 6) allocated Curvastrum near Ankistrodesmus clade. ITS-2 Secondary
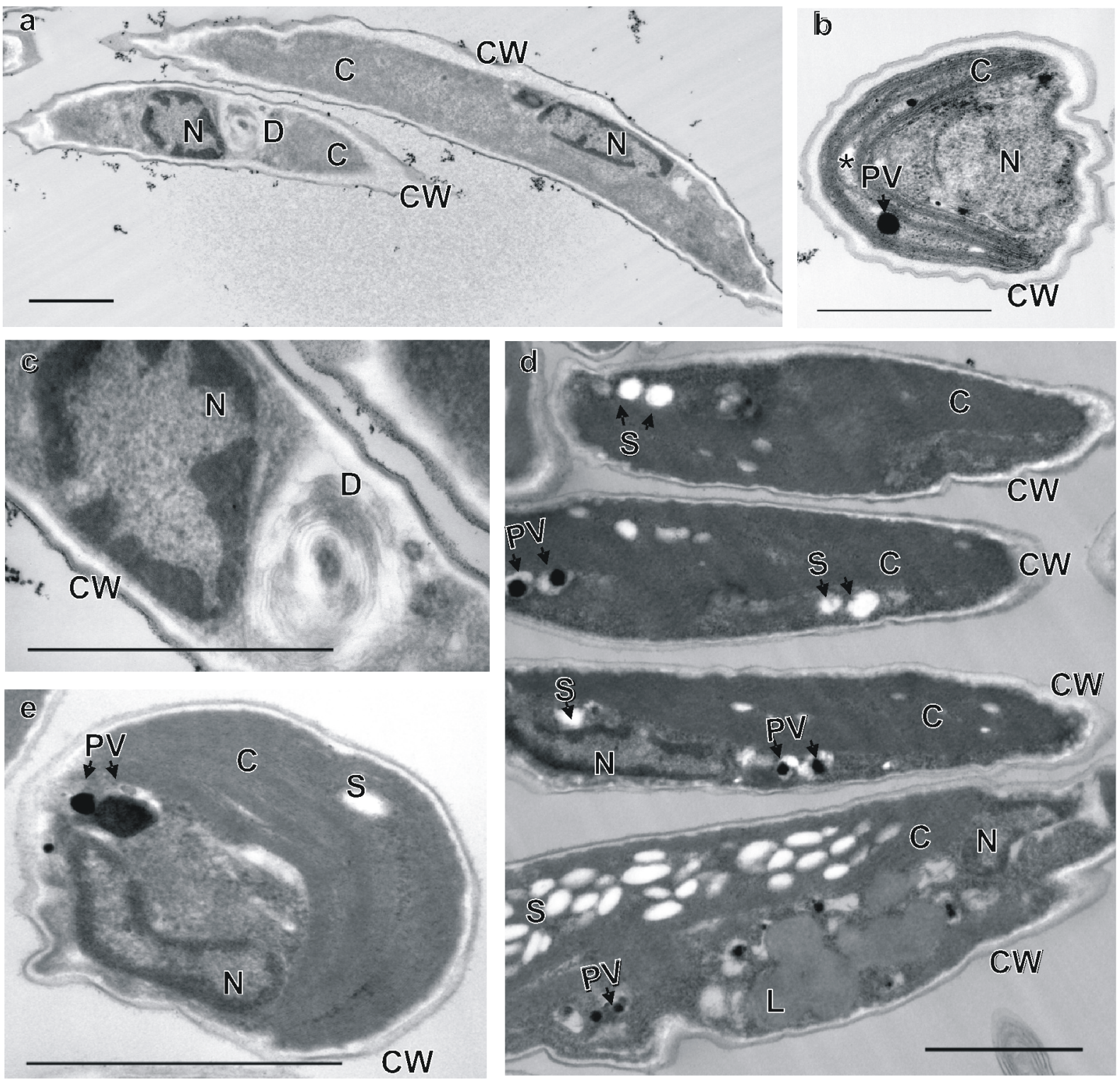

Fig. 10. Transmission electron micrographs of two Selenastraceae in culture: (a-c) Ankistrodesmus arcuatus (CCMA - UFSCar 24), (a) longitudinal section, cell with a nucleus, dictyosome and a chloroplast, (b) cross section, a cup-shaped chloroplast penetrated by a pyrenoid (star). On the opposite direction of the pyrenoid, the nucleus is situated. An arrowhead indicates a polyphosphate vacuole. (c) detail of figure a, where a dictyosome can be observed; (d-e) Monoraphidium contortum (CCMA-UFSCar 349), (d) longitudinal section; cells on different life cycle phase. The upper 3 cells are young indidivuals presenting starch grains (arrowhead), polyphosphate vacuoles (arrowhead), chloroplast and nucleus. The lower cell is a mature individual containing many starch grains on the chloroplast, some polyphosphate vacuoles (arrowhead), nucleus and big lipid drops. (e) cross section, dense chloroplast with starch grains. Two big polyphosphate vacuoles (arrowhead) and a nucleus can be observed. All the cell content is surrounded by a cell wall. Scale bar $1 \mu \mathrm{m}$. 
structure analyses showed that strains of the type species $S$. bibraianum differ from $M$. gracile type species in 34 base changes and 3 base insertions, where helix I has 1 base insertion and $6 \mathrm{CBC}$, helix II has $4 \mathrm{CBC}$, helix III has $8 \mathrm{CBC}$ and helix IV has 2 base insertions and 4 CBC (for ITS-2 secondary structure see Supplementary Fig. A-D).

Species with Ankistrodesmus designation formed two clades based on $r b c L$ (CCMA-UFSCar 423; CB 2012/3; CB2012/6; CCMA-UFSCar 593; CCMA-UFSCar 611; CB2012/29; CCMA-UFSCar 278; EF113406) and one clade on $18 \mathrm{~S}$ rDNA phylogeny (CCMA-UFSCar 277; X97352; CB2009/9; CCMAUFSCar 278; X56100). For the strain CCMA-UFSCar 24 , based on differences in $r b c L$ gene sequences and on the colony formation observed, we decided to consider this species as belonging to genus Ankistrodesmus.

Species of the genus Monoraphidium were distributed in different clades. Although using different strains, Raphidocelis was located near Monoraphidium clade I for both $r b c L$ and 18S rDNA analyses (Figs. 6 and 7). One clade constituted by $M$. contortum (strains CCMA-UFSCar 349 and CB 2009/10) was closely related to Raphidocelis microscopica. A well supported clade for Monoraphidium contortum (2 strains), Monoraphidium indicum and Monoraphidium pseudobraunii was presented on $r b c L$ phylogeny. Also, M. komarkovae, a needle-shaped representative, constituted an independent lineage on both phylogenies.

Kirchneriella species, including the type species Kirchneriella lunaris (CCMA-UFSCar 443), were distributed on some branches on both phylogenetic analyses, always close to Monoraphidium species.

Chlorolobion braunii (Chlorolobion clade) formed a well-supported clade based on $r b c L$ and made up the clade that includes sequences designated as Podohedriella falcata (X91263) and Monoraphidium neglectum (AJ300526) based on 18SrRNA gene inference with strong bootstrap support.

The species Quadrigula closterioides (BoHLIN) PRINTZ (Y17924), Tetranephris brasiliensis LeITE \& Bicudo (HM565929; HM565927), Rhombocystis complanata KOMÁREK (HM483518) and Nephrochlamys subsolitaria (WEST) KorSHIKOV (HM560960) were distributed at one branch each, on the 18S rDNA tree (Fig.7).

\section{Discussion}

This study has presented a large dataset of Selenastraceae species, including many strains of tropical environments, enlightening the phylogeny of this family. The polyphyly of some genera as Monoraphidium, Kirchneriella and Selenastrum have been confirmed, as already suggested by KRIENITZ et al.(2011, 2001) and respectively two new genera could be described.

The taxonomical placement of genera and spe- cies within the Selenastraceae using molecular data enabled pointing enhanced morphological features to distinguish the members of this complex group for traditional taxonomy, as further discussed.

\section{Morphological criteria with high taxonomic value in traditional systematics of Selenastraceae}

\section{Pyrenoids}

The presence or absence of pyrenoids is an important problem for the taxonomy of the studied genera, since using conventional light microscopy (LM), naked pyrenoids are almost impossible to detect, whereas starch covered pyrenoids are easily visualized. For that reason, most Selenastraceae were considered to be pyrenoid-less (KomÁreK \& FotT 1983; Korshikov 1953) until the study of ELORANTA (1979) that reported the presence of pyrenoids in Monoraphidium griffithii (Berkeley) KomÁrkovÁ-Legnerová, using TEM images. Later studies detected pyrenoids in all taxa studied, presenting a matrix naked or covered by starch grains (HEGEwALD et al. 1994; KRIENITZ et al. 2011; KRIENITZ et al. 1985; KRIENITZ et al. 2001). Thus, TEM is necessary for the observation of details on the pyrenoid structure (KRIENITZ et al. 2001). Furthermore, presence or absence of starch-covered pyrenoids may be not a valuable character to the Selenastraceae taxonomy when not in controlled conditions (KRIENITZ \& KLEIN 1988; MiYASHi et al. 1986).

In our study, except for Chlorolobion braunii (NÄGELI) KoMÁREK, all Selenastracean taxa studied have ellipsoidal or spherical naked pyrenoids (without starch envelopes), both investigated by LM or TEM, but they can also be spherical to irregular in Selenastraceae (see also KRIENITZ et al. 2011). C. braunii presented starched and rounded pyrenoids, as reported by KOMÁREK \& FotT (1983).

Regarding to the pyrenoid differences between genera, the thylakoid membranes permeated the pyrenoid matrix in Curvastrum pantanale and Ankistrodesmus arcuatus (Fig. 9-10), but this character demonstrated to be highly variable in the genus $A n$ kistrodesmus and Monoraphidium. Similar variation in pyrenoid structures were observed by KRIENITZ et al. (2001).

\section{Colony formation}

Traditionally used to delimit genera, colony formation is a questionable criterion. Despite the presence of colonies, many solitary cells and intermediates in the formation of colonies can be found, both in fast growing cultures (KRIENITZ et al. 2001) and in environmental samples. Many Ankistrodesmus (as an example, see KomareK \& FotT, 1983, page 689, plate 193-1), members of Kirchneriella and Chlorolobion detaches from the colonies when the reproduction begins, due to the lack of mucilage and the protoplasm differentiation process. Similarly, colonies of Ankistrodesmus 
frequently disintegrate into solitary cells and can hardly be differentiated from Monoraphidium species. Ankistrodesmus arcuatus was described as solitary cells, and for this reason, later transferred to genus Monoraphidium (Syn. Monoraphidium arcuatum). Observations on strain CCMA-UFSCar 24 on culture conditions demonstrated that this species is able to form colonies and should be realocated to genus Ankistrodesmus, data corroborated by $r b c L$ phylogeny.

\section{Arrangement of autospores}

A parallel arrangement of autospores was observed for the genera Ankistrodesmus, Chlorolobion, Messastrum, Selenastrum and Curvastrum. Monoraphidium and Kirchneriella presented both parallel and serial arrangement of autospores. For Raphidocelis species studied, Raphidocelis microscopica, the literature does not describe this feature, but it was observed serial arrangement of autospore.

While studying the ontogenesis of genera $\mathrm{An}$ kistrodesmus and Monoraphidium, KomÁRKOvÁ-LEGNEROVÁ (1969) observed that the position of autospores was found to be an invariable and stable qualitative characteristic both in nature and in culture.

\section{Cell shape and size}

Due to the high variability of these organisms on environmental samples and in culture (FAWLEY et al. 2006; KomÁrkovÁ-Legnerová 1969), criteria as cell shape and size are problematic. For some species, as Selenastrum bibraianum for example, cell shape vary during life cycle, detaching from the colony, and changing from semilunate to fusiform, with an increase in protoplasm content. Cell size is also a doubtful characteristic. The cell dimension described for A. fusiformis, for example, is big enough to accommodate $A$. fasciculatus inside the same description (KOMÁREK \& FOTT 1983).

The diacritic features of Selenastraceae have been extensively discussed. According to the numerical investigation of MARVAN et al. (1984) several genera inside Selenastraceae differ from each other by only one of the above mentioned characters. As example, Selenastrum differs from Ankistrodesmus by the curvature of the cells (KomÁreK \& Comas GonzÁlez 1982), the presence of cell wall incrustations in Raphidocelis differs it from Kirchneriella (HıNDÁK 1977), and Monoraphidium differs from Chlorolobion by the absence of starched pyrenoid (HeYNIG \& KRIENITZ 1982; KomÁREK 1979). Indeed, these examples could be observed on $r b c L$ inference (Fig.6).

Morphological features associated with $18 \mathrm{~S}$ rDNA in Selenastraceae showed that a morphotype can represent different phylotypes, suggesting that the diversity of the family has been considerably underestimated (FAwLEY et al. 2006).

Overall a combination of colony formation, presence/absence of starched pyrenoid and cell shape and size were valuable for the taxonomy of the selenastracean strains.

\section{Remarks on genera \\ Selenastrum, Messastrum and Curvastrum}

The phylogenetic inference of $r b c L$ and $18 \mathrm{~S} \mathrm{rDNA}$ (see Figs 6, 7) showed that Selenastrum bibraianum (syn. Ankistrodesmus bibraianus), Selenastrum gracile (syn. Ankistrodesmus gracilis) and Curvastrum pantanale represent unrelated lineages. Previous works had presented similar data for Selenastrum and Messastrum (FAwley et al. 2006; Krienitz et al. 2001; Krienitz et al. 2011), but no taxonomical change was made based on molecular data. The differences between the ITS-2 secondary structure, $18 \mathrm{~S}$ rDNA and $r b c L$ of the type species S. bibraianum, M. gracile and $C$. pantanale (for ITS-2 secondary structure see supplemental material) were enough to suggest the new genera. Selenastrum is distinct from Messastrum as indicated by phylogenetic interference and by eight $\mathrm{CBCs}$ in the conserved region of Helix III of the ITS2, which has been considered as reliable criterion for differentiation at species (COLEMAN 2009) and higher taxonomic levels (Coleman 2007; 2010).

Curvastrum pantanale sp. nov. is a new genus, proposed by the $18 \mathrm{~S}$ rDNA and $r b c L$ inference and only one diacritical morphological character (number of cells in colony).

\section{Ankistrodesmus}

All Ankistrodesmus-like strains studied were fusiform, isopolar, arcuate or needle-shaped, with parallel arrangement of autospores. Both phylogenies (Figs 6, 7) closely related all Ankistrodesmus strains. It was possible to recognize the genus using both phylogenies (Figs 6,7), but not species within it, since the strains share very similar morphological traits and present a low number of variable positions in the sequences of $r b c L$ and $18 \mathrm{~S}$ rDNA.

The strain Ankistrodesmus nannoselene (SAG 202.6), a halfmoon-shaped or croissant-shaped solitary representative, seem to be related to Kirchneriella species and is not clearly positioned in Selenastraceae (Bock et al. 2011a; KRIENITZ \& Bock 2012).

Molecular data revealed that Monoraphidium arcuatus (syn. Ankistrodesmus arcuatus), here represented by strain CCMA-UFSCar 24, should be recognized as belonging to genus Ankistrodesmus (Fig.6), since it shows a typical colony formation when attached to a mucilage aggregate (Fig 5 - arrowhead).

\section{Monoraphidium}

On our rbcL inference, Monoraphidium contortum showed the same morphotype for different phylotypes, feature also found by FAWLEY et al.(2006) for Monoraphidium.

The morphology diversity inside Monoraphidi$u m$ has a huge range of variations, including fusiform 
to straight cells, spiral to thin crescent-shaped organisms. The absence of typus generis Monoraphidium griffthii on this study did not allow the identification of real Monoraphidium clade. Further studies including more representatives of Monoraphidium are necessary to elucidate inter and intraspecific relations and designate new genera. The diacritic characters settled for the other genera in Selenastraceae could not distinguish all Monoraphidium species.

Two strains of Monoraphidium convolutum, one Raphidocelis subcapitata (KorSHIKOv) NyGAARD, Komárek, Kristiansen \& Skulberg and Monoraphidium dybowskii (WoloszynsKa) HindÁK \& KomÁRKOvALEGNEROVÁ were closely related and these relationships were supported statistically. Recent study (KRIENITZ et al. 2011) placed M. convolutum and Monoraphidium dybowskii as insertae sedis in Selenastraceae, emphasizing that future studies should be done.

As well as for the genus Monoraphidium, other genera as Quadrigula and Nephroclamys need further studies based on larger taxon sampling.

\section{Raphidocelis and Kirchneriella}

On our $r b c L$ inference, Raphidocelis microscopica was closely related to $M$. contortum (strains CCMA-UFSCar 349 and CB 2009/10). This species presents conical, isopolar and capricornutum shape differing from $M$. contortum by cell shape, autospore arrangement, and colony formation.

Further investigations for the genus Kirchneriella is needed due to the lack of molecular data. Only two sequences for the same strain $(K$. aperta - SAG 2004) were available on NCBI. As observed on both phylogenies, Kirchneriella species present diverse phylotypes inside one morphotype, always closely related to Monoraphidium-like members, suggesting that the different morphotypes applied for both genera hides similar genotypes. Similar findings were obtained for Dictyosphaerium, which morphotypes formed distinct lineages inside Chlorella and Parachlorella, presenting independent evolution and confirming the polyphyletic origin of the Dictyosphaerium morphotype within the Chlorellaceae (Luo et al. 2010).

\section{Chorolobion}

On the 18S rDNA tree, Chlorolobion braunii clustered in one well supported branch, with Podohedriella falcata and Monoraphidium neglectum. We could observe that the strains SAG 202-2, SAG 48.87 analyzed by KRIENITZ et al. (2001), and our strains CCMA-UFSCar 137, 462, 477 and 476 refer to three different morphological species. The small difference between these three taxa (up to 20 variable sequence positions) on $18 \mathrm{~S}$ rDNA was not enough to separate the different morphotypes. Based on 18S rDNA, the distinction among Podohedriella, Monoraphidium, and Chlorolobion remains unclear. However, for $r b c L$ inference, the four Chlorolobion braunii formed a well-supported clade, with no sequences for $P$. falcata and $M$. neglectum. Thus, since there is few molecular data and the morphology is too similar, not enforcing a nomenclatural change, we maintained our strains as belonging to genus Chlorolobion. The numbers of variable sequence positions on $18 \mathrm{~S}$ rDNA among these six taxa were $0-2$.

The main morphological differences are that Chlorolobion braunii own starch sheathed pyrenoids (KomÁreK \& FotT 1983), is fusiform, with serial arrangement of autospores; Podohedriella falcata is needle-shaped, representing one of the few periphytic Selenastraceae (DüRINGER 1958; HiNdÁK 1988), and M. neglectum have naked pyrenoids serially arranged (KrIENITZ et al. 2001).

Thus, based on morphology and $r b c L$ analysis, we maintained our strains as belonging to genus Chlorolobion.

\section{General view}

Selenastraceae, at this moment, is composed of eleven genera. Except for Ourococcus GroBÉTY representatives of all the other ten genera were represented in our phylogenetic study as well as in other previous studies (FuČ́́KOvÁ et al. 2014; KRIENITZ \& Bock 2012).

A joined analysis of $r b c L$ and $18 \mathrm{~S}$ rRNA gene data sets is used in some studies of algal phylogeny (RINDI et al. 2007), since 18S rRNA gene is too conserved to elucidate the phylogenetic trends at genus and species levels. Accordingly, due to the lower variation of the 18S rRNA sequences observed in this study, a better resolution of this group was achieved by using a more variable marker, the $r b c L$. This gene had higher sequence divergence in Selenastraceae, and, therefore, was more useful than the $18 \mathrm{~S}$ rDNA gene for phylogenetic inference at the genus and species levels. In most algal groups this is commonly the case (GURGEL \& FredericQ 2004; Hayden \& WaAland 2002; HepperLE et al. 1998; HoHAmet al. 2002; MülLer et al. 2002). Using both genes, the substantial number of variable sequence positions among the studied taxa (0-76 for 18S rRNA and 0-86 for $r b c L$ ) revealed the relationship patterns within Selenastraceae.

An usual problem in the systematics of Selenastraceae was the absence or a low bootstrap support for the basis of the trees and a good support only of smaller groups of species or genera (FAWLEY et al. 2006; KRIENITZ et al. 2001). However, our clusters are in agreement with previous studies in Selenastraceae (FAWLEY et al. 2006; KriEnITZ et al. 2011; KRIENITZ et al. 2001), supporting the probability of the phylogenetic information on the branches, despite some low bootstrap values.

Since the species concept proposed by MAYR (1942) cannot be applied to coccoid green algae, limnologists adopted the morphological species concept using morphology based diacritical characteristics as a way to deal with this limitation (KRIENITZ \& Bock 2012).

In addition to the phenotype, discussions about 
species concepts should consider intraspecific genetic variation (Hıт 2006). The description of well-established species, with known phenotypic population, should be completed by molecular, genetic, physiological, and biochemical features of all those cultured strains that follow to the original type description (Wood \& Leatham 1992), leading to the resolution of taxonomic position of morphological variants from the type.

Taxonomical value of diacritic features was discussed based on morphology or ultrastructure (KRIENITZ et al. 2001) suggesting that the concept of "small genera" (КомÁreK \& Fotт 1983) including only a few species for the Selenastraceae is not appropriated, since the existence of many transitional forms, and many diacritic features are considered not reliable (FAwLEY et al. 2006). Since it was detected real phylogenetic lineages in this family, conceiving 'small' genera was considered uncertain for Selenastraceae (KRIENITZ et al. 2001). However, some genera presented a set of diacritic characteristics. For its wide variability, the establishment of mucilage as diacritic feature is of limited taxonomic value (KrienITZ et al. 2012). Our findings suggest that the small genera concept could be applied to Monoraphidium, Kirchneriella and also for Selenastrum and Messastrum.

Although establishing smaller genera, differentiated from other genera by only a few diacritic characteristics and containing only a few numbers of species, is a trend (Luo et al. 2010). On the last decades some studies have divided previous morphological well established genus in many smaller ones, as proposed for Scenedesmus (An et al. 1999; Krienitz et al. 2003) and Pediastrum (Buchнеiм et al. 2005). Scenedesmus Meyen has been differentiated in seven genera: Scenedesmus, Acutodesmus (Hegewald) Tsarenko, Desmodesmus Chodat, Hylodesmus Elíšs, NĚmcová, ŠKaloud, Neustupa, Kaufnerová \& Šejnohová, Neodesmus Hindák, Verrucodesmus Hegewald and Chodatodesmus Hegewald, Bock \& Krientz (An et al. 1999; EliÁš et al. 2010; Krienitz et al. 2003; Hegewald et al. 2013). Studies on Chlorellaceae (Luo et al. 2010) differentiated six genera within the Chlorella clade of Chlorellaceae, mostly by molecular criteria (18S rDNA and ITS-1 and -2) and revealed that several morphological criteria (mucilage and connecting strands, colonial versus solitary life form and bristle formation) are phenotypic characteristics, representing adaptive responses to environmental factors such as grazing pressure, endosymbiosis or edaphic life strategies.

If in one hand some species may present phenotypic plasticity, on the other hand, analogous morphotypes could hide high genotypic diversity. Crescent-shaped Selenastraceae isolates of belonging to the same morphospecies were found by FAwLEY et al. (2006), with differences regarding 18S rDNA (KRIENITZ et al. 2011) for the same morphotypes studied. High levels of variability among isolates concerned to a par- ticular taxon could actually represent numerous taxa (KomÁrková-Legnerová 1969; NygaArd \& Komarek 1986).

Despite the possible phenotypical plasticity, the molecular analyses associated with morphological review in different growth phases of the phytoplankton strains, showed that some morphological criteria are important for the systematics of Selenastraceae on genus and species level. Cell shape and size, colony formation, and arrangement of autospores in the mother cell wall demonstrated to be useful for genera separation, but should be applied carefully inside species. The observation of a substantial number of colonies and solitary organisms (10-50 individuals) and observation of the whole life cycle, with special emphasis to autospores liberation and the initial colony formation, should be done in order to identify a taxon.

Unfortunately, some species description were published with missing information on the original publication, regarding morphological information (including plates) not covering all the necessary information to identify many taxa (for morphological references see material and methods). Although $18 \mathrm{~S}$ rDNA and $r b c L$ were important, morphological characteristics were observed and considered individually (morphology or genetic data) for taxonomical decisions.

However, Monoraphidium and Kirchneriella seem to be polyphyletic genera and therefore these traditional traits could not be employed, otherwise the identification would not be reliable.

Evidently, there might be a huge number of lineages within the Selenastraceae that are not covered by our study. Unfortunately, no cultures are available for hundreds of taxa designated in this cosmopolitan family and some strains are difficult to obtain all the target genes.

Thus, more efforts and new studies with isolated and cultivable strains are necessary. The many sequences from taxonomic and phylogenetic studies submitted to databases, are fundamental to be used as references for future practical applications and scientific studies (JI et al. 2013), including metabarcoding approaches. The increasingly community studies using high-throughput sequencing still lacks references for phytoplankton species (EILER et al. 2012; PAwLOwSKI et al. 2012).

The coccoid green algae are important in ecosystem studies but little information is available about its geographic distributions, even with the improvement of the taxonomy (NORTON et al. 1996; PADISÁK et al. 2015). It is estimated that exists around 14900 freshwater phytoplankton species (BouRrelLy 1990). Species richness in freshwater lakes has been claimed to be significantly higher in temperate lakes than in tropical ones (LewIS JR 1978), but this result could be also a consequence of the poorly exploration and understanding about green microalgae diversity and phylogeny in the tropics. 
ACKNOWLEDGEMENTS

The authors would like to thank Fundação de Amparo à Pesquisa do Estado de São Paulo (FAPESP, Processes: 2011/50054-4, 2012/19520-1, 2013/17457-3 and 2013/18083-0) for financial and scientific support and scholarships granted and the staff at the IMCES imaging facility for their help and assistance with imaging.

\section{REFERENCES}

An, S.; Friedl, T. \& Hegewald, E. (1999): Phylogenetic Relationships of Scenedesmus and Scenedesmus-like Coccoid Green Algae as Inferred from ITS-2 rDNA Sequence Comparisons. - Plant Biology 1: 418-428.

Bock, C.; Krienitz, L. \& Pröschold, T. (2011a): Taxonomic reassessment of the genus Chlorella (Trebouxiophyceae) using molecular signatures (barcodes), including description of seven new species. - Fottea 11: 293-312.

Bock, C.; Pröschold, T. \& Krienitz, L. (2011b): Updating the genus Dictyosphaerium and description of $\mathrm{Mu}$ cidosphaerium gen. nov. (Trebouxiophyceae) based on morphological and molecular data. - Journal of Phycology 47: 638-652.

Booton, G.C.; Floyd, G.L. \& Fuerst, P.A. (1998): Origins and affinities of the filamentous green algal orders Chaetophorales and Oedogoniales based on $18 \mathrm{~S}$ rRNA gene sequences. - Journal of Phycology 34: 312-318

Bourrelly, P. (1990): Les Algues d'eau douce. Initation a la Systématique, I: Les Algues Vertes. - 572pp. N Boubée \& Cie, Paris.

Buchheim, M.; Buchheim, J.; Carlson, T.; Braband, A.; Hepperle, D.; Krienitz, L.; Wolf, M. \& Hegewald, E. (2005): Phylogeny of the Hydrodictyaceae (Chlorophyceae): inferences from rDNA data. - Journal of Phycology 41: 1039-1054.

Buchheim, M.A.; Michalopulos, E.A. \& Buchheim, J.A. (2001): Phylogeny of the Chlorophyceae with special reference to the Sphaeropleales: a study of $18 \mathrm{~S}$ and 26S rDNA data. - Journal of Phycology 37: 819-835.

BYun, Y. \& HAN, K. (2009): PseudoViewer3: generating planar drawings of large-scale RNA structures with pseudoknots. - Bioinformatics 25: 1435-1437.

Coleman, A.W. (2003): ITS2 is a double-edged tool for eukaryote evolutionary comparisons. - Trends in Genetics 19: 370-375.

Coleman, A.W. (2007): Pan-eukaryote ITS2 homologies revealed by RNA secondary structure. - Nucleic Acids Research 35: 3322-3329.

Coleman, A.W. (2009): Is there a molecular key to the level of "biological species" in eukaryotes? A DNA guide. - Molecular Phylogenetics and Evolution 50: 197203

Coleman, A.W. \& Vacquier, V.D. (2002): Exploring the phylogenetic utility of ITS sequences for animals: a test case for abalone (Haliotis). - Journal of molecular evolution 54: 246-257.

Comas, A. (1996): Las Chlorococcales dulciacuícolas de Cuba. Bibliotheca Phycologica 99. - 192pp., J. Cramer, Berlin.

DÜRINGER, I. (1958): Über die Verteilung epiphytischer Algen auf den Blättern wasserbewohnender Angiospermen sowie systematisch-entwicklungsgeschichtliche Be- merkungen über einige grüne Algen. - Plant Systematics and Evolution 105: 1-43.

Eiler, A.; Drakare, S.; Bertilsson, S.; Pernthaler, J.; PeuRA, S.; Rofner, C.; SimeK, K.; YANG, Y. ;ZnACHOR, P. \& Lindström E. S. (2013): Unveiling distribution patterns of freshwater phytoplankton by a next generation sequencing based approach. - PLoS ONE 8: e53516.

Eliáš, M.; NĚmcová, Y.; ŠKaloud, P.; Neustupa, J.; KaufNEROVÁ, V. \& Šejnohová., L. (2009): Hylodesmus singaporensis gen. et sp. nov., a novel autosporic subaerial green alga (Scenedesmaceae, Chlorophyta) from Singapore. -International Journal of Systematic and Evolutionary Microbiology 60: 1224-1235.

Eloranta, V. (1979): The compound internal pyrenoid in cultured cells of the green alga Monoraphidium griffithii (Berkel.) Komar.-Legner. - Protoplasma 99: 229-235.

Fawley, M.W.; Dean, M.L.; Dimmer, S.K. \& Fawley, K.P. (2006): Evaluating the morphospecies concept in the Selenastraceae (Chlorophyceae, Chlorophyta).Journal of Phycology 42: 142-154.

FRIEDL, T. (1995): Inferring taxonomic positions and testing genus level assignments in coccoid green lichen algae: a phylogenetic analysis of 18 s ribosomal rna sequences from Dictyochloropsis reticulata and from members of the genus Myrmecia (Chlorophyta, Trebouxiophyceae Cl. Nov.). - Journal of Phycology 31: 632-639.

FučíkovÁ, K; Lewis, P.O.; GonzÁlez-Halphen, D. \& LewIS, L. A. (2014): Gene arrangement convergence, diverse intron content, and genetic code modifications in mitochondrial genomes of Sphaeropleales (Chlorophyta). - Genome biology and evolution 6: 2170-2180

FučíkovÁ, K.; RadA, J.C.; LuKešová, A. \& Lewis, L.A. (2011): Cryptic diversity within the genus Pseudomuriella Hanagata (Chlorophyta, Chlorophyceae, Sphaeropleales) assessed using four barcode markers. - Nova Hedwigia 93: 29-46.

Gruber, A. R.; Lorenz, R.; Bernhart, S.H.; NeubÖck, R.; \& HofACKeR, I.L. (2008): The vienna RNA websuite. Nucleic acids research 36: W70-W74.

Guillard, R.R. \& Lorenzen, C.J. (1972): Yellow-green algae with chlorophyllide C1, 2. - Journal of Phycology 8: 10-14.

Gurgel, C.F.D. \& FredericQ, S. (2004): Systematics of the Gracilariaceae (Gracilariales, Rhodophyta): a critical assessment based on $r b c L$ sequence analyses. - Journal of Phycology 40: 138-159.

Hayden, H.S. \& Waaland, J.R. (2002): Phylogenetic systematics of the Ulvaceae (Ulvales, Ulvophyceae) using chloroplast and nuclear dna sequences. - Journal of Phycology 38: 1200-1212.

Hegewald, E.; Bock, C. \& Krienitz, L. (2013): A phylogenetic study on Scenedesmaceae with the description of a new species of Pectinodesmus and the new genera Verrucodesmus and Chodatodesmus (Chlorophyta, Chlorophyceae). - Fottea 14: 149-164.

Hegewald, E. \& Hanagata, N. (2000): Phylogenetic studies on Scenedesmaceae (Chlorophyta). - Archiv für Hydrobiologie Supplementband, Algological Studies 136: 29-49.

Hegewald, E.; Krienitz, L. \& Schnepf, E. (1994): Studies on Scenedesmus costato-granulatus Skuja. - Nova 
Hedwigia 59: 97-128.

Hepperle, D. (2004): Align Ver. 07/04@. Multisequence alignment-editor and preparation/manipulation of phylogenetic datasets. Win32-Version. Distributed by the author via: http://www. sequentix. de.

Hepperle, D.; Nozaki, H.; Hohenberger, S.; Huss, V.; MoriTA, E. \& Krienitz, L. (1998): Phylogenetic position of the Phacotaceae within the Chlamydophyceae as revealed by analysis of $18 \mathrm{~S}$ rDNA and $r b c L$ sequences. - Journal of Molecular Evolution 47: 420-430.

Heynig, H. \& Krienitz, L. (1982):Monoraphidium neglectum n. sp. sowie einige Bemerkungen zu den Gattungen Monoraphidium, Chlorolobion und Keratococcus (Chlorococcales). - Archiv für Protistenkunde 125: 335-344.

HILt, S. (2006): Allelopathic inhibition of epiphytes by submerged macrophytes. - Aquatic Botany 85: 252-256. doi: DOI 10.1016/j.aquabot.2006.05.004.

Hindék, F. (1977): Studies on the chlorococcal algae (Chlorophyceae). Biol. Práce 23: 1-292.

HINDÁK, F. (1980): Studies on the chlorococcal algae (Chlorophyceae) - II.Biol. Práce 26: 1-296.

HindÁk, F. (1984): Studies on the chlorococcal algae (Chlorophyceae) - III.Biol. Práce 30: 1-263.

HindÁk, F. (1988): Studies on the chlorococcal algae (Chlorophyceae). - IV. Biol. Práce 34: 1-320.

HINDÁK, F. (1990): Studies on the chlorococcal algae (Chlorophyceae). - V.Biol. Práce 36: 1-227.

Hoham, R.W.; Bonome, T.A.; Martin, C.W. \& LeebensMACK, J.H. (2002): A combined 18s rDNA and rbcL phylogenetic analysis of Chloromonas and Chlamydomonas (Chlorophyceae, Volvocales) emphasizing snow and other cold-temperature habitats. - Journal of phycology 38: 1051-1064.

Huelsenbeck, J.P. \& Ronquist, F. (2001): MRBAYES: Bayesian inference of phylogenetic trees. - Bioinformatics 17: 754-755.

Huss, V.A.; Frank, C.; Hartmann, E.C.; Hirmer, M.; KloBoucek, A.; Seidel, B. M.; Wenzeler, P. \& Kessler, E. (1999): Biochemical taxonomy and molecular phylogeny of the genus Chlorella sensu lato (Chlorophyta). - Journal of Phycology 35: 587-598.

Ji, Y.; Ashton, L.; Pedley, S.M.; Edwards, D.P.; Tang, Y.; NaKamura, A.; Kitching, R.; Dolman, P.M.; WoodCOCK, P. \& EDWARDS, F.A. (2013): Reliable, verifiable and efficient monitoring of biodiversity via metabarcoding. - Ecology letters 16: 1245-1257.

Joвв, G. (2008): TREEFINDER version of October 2008. Munich, Germany Distributed by the author at www. Treefinder.de.

Katana, A.; Kwiatowski, J.; Spalik, K.; Zakryś, B.; SzaLacha, E. \& SzymańsKa, H. (2001): Phylogenetic position of Koliella (Chlorophyta) as inferred from nuclear and chloroplast small subunit rDNA. - Journal of Phycology 37: 443-451.

KomÁReK, J. (1979): Änderungen in der Taxonomie der Chlorokokkalalgen. - Algological Studies/Archiv für Hydrobiologie, Supplement Volumes: 239-263.

Komárek, J. \& Comas GonzÁlez, A. (1982): Taxonomical definition of the genera and several species of Ankistrodesmus and Selenastrum (Chlorococcales). - Algological Studies/Archiv für Hydrobiologie, Supplement Volumes: 259-277.

KomÁreK, J. \& FotT, B. (1983): Chlorophyceae (Grünalgen) Ordnung: Chlorococcales. - In: Huber-PestalozzI,
G. (ed.): Das Phytoplankton des Süßwassers 7. Teil, 1. Hälfte. - 1044 pp., Schweizerbart'sche Verlagsbuchhandlung (Nägele u. Obermiller), Stuttgart.

KomÁRKovÁ-Legnerová, J. (1969): The systematics and ontogenesis of the genera Ankistrodesmus Corda and Monoraphidium gen. nov. - In: Fotт, B. (ed.): Studies in Phycology. - pp. 75-122, Academia, Praha.

KorshiKov, O.A. (1953): Viznachnik prisnovodnihk vodorostey Ukrainsykoi RSR [Vyp] V. Pidklas Protokokovi (Protococcineae). Bakuol'ni (Vacuolales) ta Protokokovi (Protococcales). - 439 pp., Akad. NAUK URSR, Kyjev.

KorshiKov, O. (1987): The freshwater algae of the Ukrainian SSR- V. Sub-class Protococcineae: Vacuolales and Protococcales (translated by J. WG. Lund \& W. Tylka). - 412 pp., Koeltz Scientific Books, Köenigstein.

Krienitz, L. \& Bock, C. (2012): Present state of the systematics of planktonic coccoid green algae of inland waters. - Hydrobiologia 698: 295-326.

Krienitz, L.; Bock, C.; Kotut, K. \& PröSchold, T. (2012): Genotypic diversity of Dictyosphaerium-morphospecies (Chlorellaceae, Trebouxiophyceae) in African inland waters, including the description of four new genera. - Fottea 12: 231-253.

Krienitz, L.; Bock, C.; Nozaki, H. \& Wolf, M. (2011): SSU rRNA gene phylogeny of morphospecies affiliated to the bioassay alga "Selenastrum capricornutum" recovered the polyphyletic origin of crescent-shaped Chlorophyta. - Journal of Phycology 47: 880-893.

Krienitz, L.; Hegewald, E.; Hepperle, D. \& Wolf, M. (2003): The systematics of coccoid green algae: morphology versus $18 \mathrm{~S}$ rRNA gene phylogeny. - Biológia 58: 437-446.

Krienitz, L. \& Klein, G. (1988): Morphologie und Ultrastruktur einiger Arten der Gattung Monoraphidium (Chlorellales) III. Monoraphidium terrestre Bristol nov. comb. - Algological Studies/Archiv für Hydrobiologie, Supplement Volumes: 447-463.

Krienitz, L.; Klein, G. \& BöHM, H. (1985): Zur Morphologie und Ultrastruktur von Selenastrum gracileReinsch 1867 (Chlorellales). - Archiv für Protistenkunde 130: 79-92.

Krienitz, L.; Ustinova, I.; FriedL, T. \& Huss, V.A. (2001): Traditional generic concepts versus 18S rRNA gene phylogeny in the green algal family Selenastraceae (Chlorophyceae, Chlorophyta). - Journal of Phycology 37: 852-865.

LEWIS JR, W.M. (1978): A compositional, phytogeographical and elementary structural analysis of the phytoplankton in a tropical lake: Lake Lanao, Philippines. - The Journal of Ecology: 213-226.

LEwIS, L.A. (1997): Diversity and phylogenetic placement of Bracteacoccus Tereg (Chlorophyceae, Chlorophyta) based on 18s ribosomal RNA gene sequence data. Journal of Phycology 33: 279-285.

Luo, W.; Pröschold, T.; Bock, C. \& Krienitz, L. (2010): Generic concept in Chlorella-related coccoid green algae (Chlorophyta, Trebouxiophyceae). - Plant Biology 12: 545-553.

MANHART, J.R. (1994): Phylogenetic analysis of green plant $r b c L$ sequences. - Molecular phylogenetics and evolution 3: 114-127.

Marin, B.; Klingberg, M. \& Melkonian, M. (1998): Phylogenetic relationships among the Cryptophyta: analyses of nuclear-encoded SSU rRNA sequences 
support the monophyly of extant plastid-containing lineages. - Protist 149: 265-276.

Marvan, P.; Komárek, J. \& Comas, A. (1984): Weighting and scaling of features in numerical evaluation of coccal green algae (genera of the Selenastraceae). - Algological Studies/Archiv für Hydrobiologie, Supplement Volumes: 363-399.

MAYR, E. (1942): Systematics and the origin of species, from the viewpoint of a zoologist. - 334 pp., Columbia University Press, Columbia.

McCourt, R.M.; Karol, K.G.; Bell, J.; Helm-BychowsKI, K.M.; GrajewsKa, A.; WojcIechowsKi M.F. \& Hoshaw, R.W. (2000): Phylogeny of the conjugating green algae (Zygnemophyceae) based on $r b c L$ sequences. - Journal of Phycology 36: 747-758.

Messyasz, B. (2003): Spatial distribution of chlorococcalean genera in the phytoseston of the Wena and Nielba rivers. - Oceanological and Hydrobiological Studies 2: $33-44$.

MischKe, U. \& Kusber,W. (2009): Die harmonisierte Taxaliste des Phytoplanktons für Seen und Flüsse in Deutschland. Excel-Datei-Liste mit ausführlichen Anmerkungen.Stand 2009/05/20. Available in: http:// www.igb-berlin.de/datenbanken.html.

Miyashi, T.; Kamata M. \& Mukai, T. (1986): Oxygenation and [3+ 2]-cycloaddition of methylenecyclopropanes through electron donor-acceptor complexes with tetracyanoethylene by photoexcitation and in the dark. - Journal of the American Chemical Society 108: 2755-2757.

Müller, K.M.; Sherwood, A.R.; Pueschel, C. M.; Gutell, R.R. \& Sheath, R.G. (2002): A proposal for a new red algal order, the Thoreales. - Journal of Phycology 38: 807-820

Norton, T.A.; Melkonian, M. \& Andersen, R.A. (1996): Algal biodiversity. - Phycologia 35: 308-326.

Nozaki, H.; Itoh, M.; Sano, R.; Uchida, H.; Watanabe, M.M. \& Kuroiwa, T. (1995): Phylogenetic relationships within the colonial Volvocales (Chlorophyta) inferred from $r b c L$ gene sequence data. - Journal of Phycology 31: 970-979.

Nygaard, G.; KomáreK, J. \& Skulberg, O. (1986): Taxonomic designations of the bioassay alga, NIVA-CHL I (Selenastrum capricornutum) and some related strains. - Opera Botanica 90: 1-46.

Nylander, J. (2004): MrModeltest v2. Program distributed by the author. - Evolutionary Biology Centre, Uppsala University.

PAdisÁk, J.; VASAS, G. \& Borics, G. (2015): Phycogeography of freshwater phytoplankton: traditional knowledge and new molecular tools. - Hydrobiologia 764: 3-27.

PAnkow, H. (1990): Ostsee-Algenflora. - 648 pp., Gustav Fischer, Jena.

Pawlowski, J.; Audic, S.; Adl, S.; Bass, D.; Belbahri, L.; Berney, C.; Bowser, S.S.; Cepicka, I.; Decelle J. \& DUNTHORN, M. (2012): CBOL protist working group: barcoding eukaryotic richness beyond the animal, plant, and fungal kingdoms. - PLoS Biology 10: e1001419.

Rambaut, A. \& Drummond, A. (2007): Tracer (http://beast. bio. ed. ac. uk/Tracer). Version 1.4.

Rindi, F.; Guiry, M.D. \& López-Bautista, J.M. (2008): Distribution, morphology, And phylogeny of Klebsormidium (Klebsormidiales, Charophyceae) in urban environments in Europe. - Journal of Phycology 44:
$1529-1540$.

Rindi, F.; McIvor, L.; Sherwood, A.R.; Friedl, T.; Guiry, M.D. \& Sheath, R.G. (2007): Molecular phylogeny of the green algal order Prasiolales (Trebouxiophyceae, Chlorophyta). - Journal of Phycology 43: 811-822.

Rindi, F.; Mikhailyuk, T.I.; Sluiman, H.J.; FriedL, T. \& López-Bautista, J.M. (2011): Phylogenetic relationships in Interfilum and Klebsormidium (Klebsormidiophyceae, Streptophyta). - Molecular Phylogenetics and Evolution 58: 218-231.

Rogers, J.E.; Leblond, J.D.\&Moncreiff, C.A. (2006): Phylogenetic relationship of Alexandrium monilatum (Dinophyceae) to other Alexandrium species based on 18S ribosomal RNA gene sequences. - Harmful Algae 5: 275-280.

Rosenthal, A.; Coutelle, O. \& Craxton, M. (1993): Largescale production of DNA sequencing templates by microtitre format PCR. - Nucleic Acids Research 21: 173-174.

SAnT'AnnA, C.L. (1984): Chlorococcales (Chlorophyceae) do Estado de São Paulo, Brasil. - In: Bibliotheca Phycologica 67. - 348 pp., J. Cramer, Berlin.

SAunders, G.W. \& KuCERA, H.. (2010): An evaluation of $r b c L$, tufA, UPA, LSU and ITS as DNA barcode markers for the marine green macroalgae. - Cryptogamie Algologie 31: 487-528.

Schultz, J.; Maisel, S.; Gerlach, D.; Müller, T. \& Wolf, M. (2005): A common core of secondary structure of the internal transcribed spacer 2 (ITS2) throughout the Eukaryota. - RNA 11: 361-364.

StÖVER, B. C. \& MÜLlER, K.F. (2010): TreeGraph 2: combining and visualizing evidence from different phylogenetic analyses. - BMC bioinformatics 11: 7 .

Swofford, D.L. (2002): Phylogenetic analysis using parsimony (* and other methods), version 4.0b 10. - Sinauer Associates, Sunderland, Massachusetts.

TAs, B. \& Gonulol, A. (2007). An ecologic and taxonomic study on phytoplankton of a shallow lake, Turkey. Journal of Environmental Biology 28: 439.

Ustinova, I.; Krienitz, L. \& Huss, V.A. (2001): Closteriopsis acicularis (G. M. Smith) Belcher \& Swale is a fusiform alga closely related to Chlorella kessleri Fott \& Nováková (Chlorophyta, Trebouxiophyceae). - European Journal of Phycology 36: 341-351.

van Hannen, E.; FinkGodhe, P. \& Lurling, M. (2002): A revised secondary structure model for the internal transcribed spacer 2 of the green algae Scenedesmus and Desmodesmus and its implication for the phylogeny of these algae. - European Journal of Phycology 37: 203-208.

Wolf, M.; Chen, S.; Song, J.; Ankenbrand, M. \& Müller,T. (2013): Compensatory base changes in ITS2 secondary structures correlate with the biological species concept despite intragenomic variability in ITS2 sequences-a proof of concept. - PloS one 8: e66726.

Wood, A.M. \& Leatham, T. (1992): The species concept in phytoplankton ecology. - Journal of Phycology 28: 723-729.

Young, I. \& Coleman, A.W. (2004): The advantages of the ITS2 region of the nuclear rDNA cistron for analysis of phylogenetic relationships of insects: a Drosophila example. - Molecular phylogenetics and evolution 30: 236-242. 


\section{Supplementary material}

the following supplementary material is available for this article:

Figs A-D. (A) ITS-2 model for the type strain of Selenastrum bibraianum (CCMA-UFSCar 125); (B) ITS-2 model for the type strain of Selenastrum bibraianum (CCMA-UFSCar 125); (C) ITS-2 model for the type strain of Messastrum gracile (CCMAUFSCar 622); (D) ITS-2 model for the type strain of Curvastrum pantanale (CCMA-UFSCar 350).

Table S1. List of all strains, used to the construction of the tree in Fig. 3, with their accession numbers in GenBank and localities of origin.

Table S2. List of studied strains with origin information and GenBank accession numbers for 18S rDNA and $r b c L$ genes and ITS-2 secondary structure.

Table S3. 18S rDNA, $r b c L$ and ITS primers used for amplification and sequencing of Selenastraceae.

This material is available as part of the online article (http:// fottea.czechphycology.cz/contents)

C) Czech Phycological Society (2017)

Received November 30, 2015

Accepted March 23, 2016 